\title{
In vitro Apoptosis Induction in Prostate Cancer Cells (PC-3) using Bacillus licheniformis Supernatant
}

\author{
Ahmadreza Shahniani ${ }^{1}$, Zahra Bamzadeh ${ }^{* 2}$ id, Fahimeh Mahmoudnia ${ }^{3}$, Leila Rouhi ${ }^{4}$ \\ 1. Department of Microbiology, Faculty of Basic Sciences, Kazerun Branch, Islamic Azad University, Kazerun, Iran \\ 2. Department of Microbiology, Faculty of Basic Sciences, Shahrekord Branch, Islamic Azad University Shahrekord, Iran \\ 3. Department of Biology, Faculty of Science, Farhangian University, Tehran, Iran \\ 4. Cellular and Developmental Research Center, Faculty of Basic Sciences, Shahrekord Branch, Islamic Azad University, Shahrekord, Iran
}

\section{ABSTRACT}

Background: Cancer is one of the most common causes of death in humans. Therefore, there is a need for new cytotoxic compounds from natural sources such as native bacteria. The current study aimed at investigating the cytotoxic effects of compounds obtained from gram-positive terricolous bacteria on the apoptosis of cells in prostate cancer (PC-3).

Materials \& Methods: A total of 70 soil samples were obtained from various locations in Chaharmahal \& Bakhtiari province (Iran, Spring 2019) and were cultured on Nutrient agar and Trypticase soy agar. After identification of gram-positive species, the best species in regards to microbial activity was identified using 16S rRNA gene sequencing. Then, in order to investigate the cytotoxic activity, PC-3 cell line was treated in different concentrations of the supernatant from the selected species for different durations while viability and apoptosis were determined using MTS and Annexin tests.

Results: A total of 467 gram-positive bacteria were isolated from 70 soil samples, among which 9 species had antimicrobial capabilities. Among these selected species, Bacillus licheniformis which had the best antimicrobial compounds, was selected for further investigation of its viability and apoptosis effects on PC-3 cell line. The MTS with incubation time of 24, 48 and 72 hours of the treated cells indicated that the viability is dependent on the dosage an increase in the concentration can result in significant decrease in the viability compared to the control group $(P<0.05)$. The amount of apoptosis induction in PC-3 cells also significantly increased with increase in supernatant concentration dependent on dosage and time $(P<0.05)$. The largest effect was observed at supernatant concentration of $20 \mathrm{mg} / \mathrm{mL}$ at 72 hours after cell treatment.

Conclusion: Using compounds obtained from gram positive terricolous bacteria can help in treatment of prostate cancer cells.

Keywords: Soil, Bacillus licheniformis, Prostate Cancer, MTS, Apoptosis

Received: 2020/08/19; Accepted: 2020/09/28; Published Online: 2020/10/20

\begin{tabular}{cc} 
Received: & 2020/08/19; $\quad$ Accepted: 2020/09/28; Published Online: 2020/10/20 \\
\hline Corresponding Information: & $\begin{array}{l}\text { Zahra Bamzadeh, Ph.D of Microbiology, Department of Microbiology, Faculty of Basic Sciences, Shahrekord Branch, Islamic Azad } \\
\text { University, Shahrekord, Iran. Email: Bamzadehz@yahoo.com }\end{array}$ \\
\hline (a) 0 Copyright ( 9 2020, This is an original open-access article distributed under the terms of the Creative Commons Attribution-noncommercial 4.0 International License which \\
permits copy and redistribution of the material just in noncommercial usages with proper citation.
\end{tabular}

Download citation: BibTeX | RIS | EndNote | Medlars | ProCite | Reference Manager | RefWorks Send citation to: $\boldsymbol{\alpha}_{\text {Mendeley }} \mathbf{z}$ Zotero $\mathbb{E}_{\text {RefWorks }}$

\section{Introduction}

Today, cancer is one of the most important health challenges all over the world and $25 \%$ of death cases in the United States are due to cancer. Half of all the cancer cases occur in Asian countries which make $60 \%$ of the world population. It has been estimated that the cancer cases will increase from 6.1 million in 2008 to 10.6 million in 2030, which is due to the significant growth of the world's oldest population, and changes in the lifestyle and economic 
changes in the society (1). In the developed countries, the prostate cancer is the second most common cancer (after skin cancer) and the second deadliest cancer (after lung cancer) in men. So that, one in six men develops prostate cancer. The epidemiological studies have also shown that hereditary factors play a role in the incidence of $10 \%$ of these cases. The highest and the lowest prevalence of prostate cancer were found in Africa and Asia, respectively (2). On the other hand, the first gene locus known to be associated with the prostate cancer was the Hereditary Prostate Cancer locus-1 (HPCL). Several other candidate genes have been identified since this discovery, although most of them are less important due to their low frequency. Most of the prostate tumors are adenocarcinomas. The hereditary history of prostate cancer is an important factor in the development of this cancer. The hereditary factors are involved in a small percentage of prostate cancers and are usually associated with the early onset. In men, increased androgen levels are associated with an increased risk of prostate cancer. The androgen receptor gene plays an important role in the development and progression of prostate cancer. Also, AR, HSD3B, 2HSD3B1, SRD5A2, and CYP17 genes have a special role in the cell proliferation in androgen metabolism in prostate.

Some polymorphisms in these genes are associated with an increased risk of prostate cancer. Mutations in androgen receptor are found in almost all cases of prostate cancer, and treatment strategies for this cancer emphasize on the reducing or eliminating testosterone binding to the androgen receptor. The epigenetic changes, especially DNA hypermethylation in the promoter regions, play an important role in reducing the expression of genes important for the care and prevention of prostate cancer. A number of molecular and genetic changes have been observed in prostate cancer. These factors play a role in the onset and progression of prostate cancer. Metastasisinhibiting genes are also known in prostate cancer. The hypermethylation of promoter regions of some genes involved in apoptosis is also known in cancer.

Prostate cancer, in fact, is the presence of cancer cells in this organ, for the increased androgen level of the adrenal glands, which cause obstruction in the urinary tract $(3,4)$. The main alarming signs of the prostate cancer include: frequent or difficult urination, poor urine flow, inability to urinate, urinary incontinence, intermittent and poor urine flow, blood in the urine, painful ejaculation, persistent low back pain and sexual impotence (5). Regardless of the gender or racial origin, the strongest known risk factor in this case is a family history of the disease. Prostate cancer is the most common cancer diagnosed in American men. It is more likely for a man who does not smoke, to develop about $17 \%$ prostate cancer more than other cancers (6).
One of the diagnostic and screening methods for the prostate cancer is the prostate gland finger examination through the rectum.

Rapid diagnosis of the prostate cancer is mediated by measuring the prostate-specific antibody (PSA) using screening tests. The level of this antibody is higher in the patients with prostate cancer. In some cases, an infection or benign enlargement of the prostate gland can cause an increase in the PSA in the blood. Therefore, combining the anal examination with PSA level in the blood is a more accurate way to diagnose prostate cancer. In the next stages, other examinations such as MRI, ultrasound, computed tomography and gland sampling are performed (7).

Conventional treatment options for the prostate cancer include surgery (complete removal of the prostate gland or prostatectomy) (8), cold surgery or cold therapy (9), chemotherapy, radiotherapy, and gene therapy (10). There are various mechanisms by which these treatments are able to control various tumor cells, including induction of apoptosis, increased mitochondrial membrane permeability, and blocking transduction signals (processes that occur in the metabolic pathway) through inhibition of the key enzymes, cytomorphological changes due to impaired cell differentiation, and tumor-induced angiogenesis. Antitumor compounds produced by Streptomyces occasionally act by disrupting doublestranded DNA, leading to detrimental effects on the rapid cell proliferation by inhibiting DNA-dependent RNA polymerase activity (11).

Finally, despite the fact that there are different ways to treat cancer, cancer is still a common and public concern. Chemotherapy is one of the most effective ways to control cancer, but it requires a constant supply of the new antitumor compounds. Cancer treatment is still a major issue for the physicians and the pharmaceutical industry. More than $60 \%$ of the chemotherapeutic agents used today to treat cancer are compounds that have been identified from the soil microorganisms or compounds synthesized or derived from them with the modified properties (12). Because soil is the home to a variety of living organisms, including bacteria, fungi, protozoa, nematodes, insects, and many other living organisms. The bacterial population can reach $10^{8}$ to $10^{9}$ cells per gram of dry soil weight at soil surfaces. Soil bacteria are very diverse and can be aerobic, anaerobic or optional anaerobic. In addition, they can be heterotrophic or autotrophic in terms of nutrition (2).

Studies have shown that the soil and rhizosphere contain thousands of unique bacterial species per gram of soil. However, today only a very small part of these bacteria that are capable of producing secondary biological metabolites have been studied.

Studies have shown that strains of bacteria are able to produce a wide range of secondary metabolites encoded by gene clusters that are not expressed in vitro. Secondary 
metabolites are not directly involved in the growth, development, or proliferation of the bacteria, but these metabolites may play ecological roles in the interaction of these bacteria with other organisms (13). In other words, many microbial metabolites are essential drugs in the treatment of cancer. Their therapeutic application began from 1940 with the discovery of actinomycin, and since then many new compounds with anti-cancer properties have been identified and isolated from natural sources (12).

Finally, due to the increasing cancer prevalence, which is one of the most important and common causes of death in human, there is a need to discover new compounds and create independency in the production of anti-cancer metabolites and being independent from foreign countries. On the other hand, few studies have been done on the effect of microbial production metabolites on cancer cells. Also, the society needs to identify new biologically active compounds produced by endemic bacteria. In this study, the anti-cancer effects of metabolites extracted from Bacillus licheniformis isolated from the soil of Chaharmahal and Bakhtiari province was investigated against prostate cancer cell line (PC-3).

\section{Materials and Methods}

The present study is a cross-sectional descriptive study that the inclusion criterion is Bacillus licheniformis metabolites production and the exclusion criterion is the effect of produced metabolites on the apoptosis induction in the prostate cancer cells (PC-3).

Isolation and Identification of Gram-positive Bacteria from Soil Samples

During this study, 70 soil samples were collected from different regions of Chaharmahal and Bakhtiari province in the spring of 2019 from the depth of 10 to $15 \mathrm{~cm}$ next to the plant roots and transferred to the laboratory to isolate and identify the gram-positive bacteria (14). To identify their phenotype, following culture and purification of bacteria, the macroscopic and microscopic characteristics of each isolate were examined $(15,16)$. After initial identification, the best isolate in terms of antimicrobial compounds production with a wider range of effects was identified using molecular identification method.

\section{Molecular Identification of Gram-positive Bacteria Producing Antimicrobial Compounds}

The 16S rRNA gene sequence was used for the genotypic identification. First, DNA extraction was performed using DNA extraction kit (CinnaGen, Iran). Then, to ensure the purity of DNA, the light absorption of the sample was measured at 260/280 nm wavelength. If the DNA sample is pure, the ratio should be above 1.8, otherwise, the DNA is considered impure. Forward and reverse primers for 16S rRNA gene were synthesized by CinnaGen Company (Table 1).

Table 1. Primers sequences for 16s rRNA gene (17).

\begin{tabular}{|cc|}
\hline Primer & Sequence $\left(5^{\prime} \rightarrow 3^{\prime}\right)$ \\
\hline $1000 F 16$ & CAACGAGCGCAACCC \\
\hline $1429 R$ & GGTTACCTTGTTACGACT \\
\hline
\end{tabular}

To prepare a master mix with a volume of $25 \mu \mathrm{L}$, sterile distilled water $(18 \mu \mathrm{L})$ was mixed with 10X PCR buffer with $(2.5 \mu \mathrm{L}), 0.75 \mu \mathrm{L} \mathrm{MgCl} 2,0.5 \mu \mathrm{L} d N T P, 1 \mu \mathrm{L}$ forward and reverse primers $(10 \mathrm{pmol} / \mu \mathrm{L}), 0.25 \mu \mathrm{L}$ polymerase enzyme and $1 \mu \mathrm{L}$ of template DNA. Finally, the PCR program was performed by thermal cycling apparatus (Eppendorf, Germany). To start the polymerization process, the thermal cycling machine was set at $95^{\circ} \mathrm{C}$ for $180 \mathrm{sec}$, followed by 35 cycles of $95^{\circ} \mathrm{C}$ for $60 \mathrm{sec}, 56^{\circ} \mathrm{C}$ for $45 \mathrm{sec}$ and $72^{\circ} \mathrm{C}$ for $60 \mathrm{sec}$. Final elongation was performed at $72^{\circ} \mathrm{C}$ for $300 \mathrm{sec}$ (17). To confirm the amplification of $16 \mathrm{~S}$ rRNA gene, the PCR product was electrophoresed on $1 \%$ agarose gel. The PCR product was sent to Macrogene Co., Korea for sequencing. The obtained sequence was evaluated using BLAST software of NCBI (17).

\section{Bacillus licheniformis Culture}

In order to isolate the products, Bacillus licheniformis was cultured in TSB (Trypticase Soy Broth) medium for
$48 \mathrm{hr}$, and then centrifuged at $12000 \mathrm{~g}$ for $10 \mathrm{~min}$. The cells were separated from supernatant. The supernatant was used to evaluate the cytotoxic activity. For this purpose, the supernatant was lyophilized for $7 \mathrm{hr}$ and then dried. The samples were stored at $-20^{\circ} \mathrm{C}$ until use (14).

\section{Cytotoxic Effects of Bacillus licheniformis Supernatant on PC-3 Cancer Cell}

The PC-3 prostate cancer cell line that is used for the prostate cancer research and drug production was obtained from the Pasteur Institute of Iran. The PC-3 cell line was derived in 1979 from grade 4 bone metastasis of prostate cancer from a 62-year-old Caucasian man. After transferring the flask to the lab, the cell media was removed and fresh medium (RPMI + FBS10\% + Pen / Strep1\%) (Sigma Company) was added and incubated at $37^{\circ} \mathrm{C}, 5 \% \mathrm{CO}_{2}$ and $95 \% \mathrm{O}_{2}$ atmosphere.

To investigate the effect of Bacillus licheniformis supernatant on the prostate cancer cells apoptosis, 
the cells were exposed to different concentrations. The experimental groups included: Group I: Cells were exposed to $5 \mathrm{mg} / \mathrm{ml}$ concentration of Bacillus licheniformis supernatant. Group II: Cells were exposed to $10 \mathrm{mg} / \mathrm{ml}$ concentration of Bacillus licheniformis supernatant. Group III: Cells were exposed to $15 \mathrm{mg} / \mathrm{ml}$ concentration of Bacillus licheniformis supernatant. Group IV: Cells were exposed to $20 \mathrm{mg} / \mathrm{ml}$ concentration of Bacillus licheniformis supernatant. Control group: Cells were exposed to RPMI1640 culture medium.

The MTS kit (Promega) is a quantitative and colorimetric assay. The MTS is reduced by the mitochondrial enzyme succinate dehydrogenase in living cells. Briefly, the cells were cultured into 96-well plate $\left(5 \times 10^{3}\right.$ cell/well). After $24 \mathrm{hr}$ and cell confluency, the supernatant was replaced with new media containing different concentrations of metabolite (5, 10, 15 and $20 \mathrm{mg} / \mathrm{mL}$ for groups I, II, III and IV, respectively) and the cells were incubated for 24,48 and $72 \mathrm{hr}$. Untreated cells were considered as control. After the incubation times, $20 \mu \mathrm{L}$ of MTS solution was added to each well and incubated for $4 \mathrm{hr}$. The intensity of the color was determined by ELISA reader at $492 \mathrm{~nm}$ wavelength. All the experiments were repeated three times and the data were expressed as mean \pm SD (18).

\section{Apoptosis Assay}

The apoptosis induction was assessed using FITC Annexin V Apoptosis Detection Kit with $\mathrm{PI}$, product number 556547 (BD Pharmingen, USA). The concentrations of $5,10,15$ and $20 \mathrm{mg} / \mathrm{ml}$ of the metabolite at intervals of 24,48 and $72 \mathrm{hr}$ were used to evaluate the apoptosis. The cells were trypsinized, harvested and centrifuged after washing with PBS (Gibco, USA). The Annexin-V dye bound to FITC and
Propidium iodide $(\mathrm{PI})$ were added $(5 \mu \mathrm{L})$ and incubated for $15 \mathrm{~min}$ at room temperature in dark and evaluated by flow cytometry (FACSCalibur, USA) (18).

\section{Statistical Analysis}

Data statistical analysis was performed by SPSS software using t-test and ANOVA parametric test. To determine the significant difference between the treated groups and the control group, the $\mathrm{P}<0.05$ was calculated as a significant difference and the results were shown as the mean \pm SD.

\section{Results}

After collecting and preparing 70 soil samples from different regions of Chaharmahal and Bakhtiari province, the screening steps were performed on each sample separately. From the culture of soil samples on the nutrient agar and tryptide soy agar and purification of the obtained colonies, 467 gram-positive bacterial colonies were isolated. Among them, 9 gram-positive isolates with the ability to produce antimicrobial metabolites were identified. The best isolate in terms of antimicrobial compounds production with a wider range of effects was identified by molecular identification technique. The 16S rRNA alignment results showed that Bacillus licheniformis is the best strain in terms of antimicrobial compounds production (Figure 1). Finally, the selected strain was used to evaluate the cytotoxic effects.

\section{Cytotoxic Results of Bacillus licheniformis Supernatant on PC-3 Cell Line}

The microscopic observations showed the morphological changes and a decrease in the cell number in the treated groups in a concentration- and time-dependent manner (Figures 2 and 3 ).

Bacillus licheniformis gene for 16S rRNA, partial sequence

Sequence ID: dbj|AB275356.1| Length: 1501

\begin{tabular}{lcccc}
\hline Score & Expect & Identities & Gaps & Strand \\
\hline $\mathbf{5 5 5}$ bits(300) & 2e-154 & $348 / 371(94 \%)$ & $4 / 371(1 \%)$ & Plus/Plus \\
\hline
\end{tabular}

Query 16 TTGCGGC-CTCTAAGGTGACTGCCGGTGA-TAACCGGAGGAAgggggggATGACGTCAAA 73

||| ||| |||||||||||||||||||| ||||||||||||| |||||||||||||||

Sbjct 1126 TTG-GGCACTCTAAGGTGACTGCCGGTGACAAACCGGAGGAAGGTGGGGATGACGTCAAA 1184

Query 74 TCATCCTGCCCCTTATGACCTGGGCTACCCACGTGCTACAATGGGCATAACAAAGGGCAA 133
$|\|||||||||||||||||||||||||||||||||||||||||||||||||||| \mid$

Sbjct 1185 TCATCATGCCCCTTATGACCTGGGCTACACACGTGCTACAATGGGCAGAACAAAGGGCAG 1244

Query 134 CGAACCCCCGAGGCTAAGCCAATCCCACAAATCTGTTCTCAATTCGGATCGCAATCTGCA 193 
|||| || |||||||||||||||||||||||||||||||| ||||||||||| ||||||

Sbjct 1245 CGAAGCCGCGAGGCTAAGCCAATCCCACAAATCTGTTCTCAGTTCGGATCGCAGTCTGCA 1304

Query 194 ACTCCACTGCCTGAAGCTGGAATCCCTAGTAATCCCGGATCAACATGCCGCGGTGAATAC 253

|||| ||||| |||||||||||| ||||||||| ||||||| ||||||||||||||||

Sbjct 1305 ACTCGACTGCGTGAAGCTGGAATCGCTAGTAATCGCGGATCAGCATGCCGCGGTGAATAC 1364

Query 254 CTTCCCGGGCCTTGTACACACCGCCCGTCACACCACGAGAGTTTGTAACACCCGAAGTCG 313

||||||||||||||||||||||||||||||||||||||||||||||||||||||||||

Sbjct 1365 GTTCCCGGGCCTTGTACACACCGCCCGTCACACCACGAGAGTTTGTAACACCCGAAGTCG 1424

Query 314 GTGAGGTAACCTTTTGGAACCAGCCGCCCAAGGTGGGACAGATGATTGGGGTGAAGTCGT 373

||||||||||||||||| ||||||||| ||||||||||||||||||||||||||||||

Sbjct 1425 GTGAGGTAACCTTTTGGAGCCAGCCGCCGAAGGTGGGACAGATGATTGGGGTGAAGTCGT 1484

Query 374 A-CATGTAACC 383

| || |||||

Sbjct 1485 AACAGGTAACC 1495

Figure 1. The 16S rRNA gene alignment analysis of the selected strain
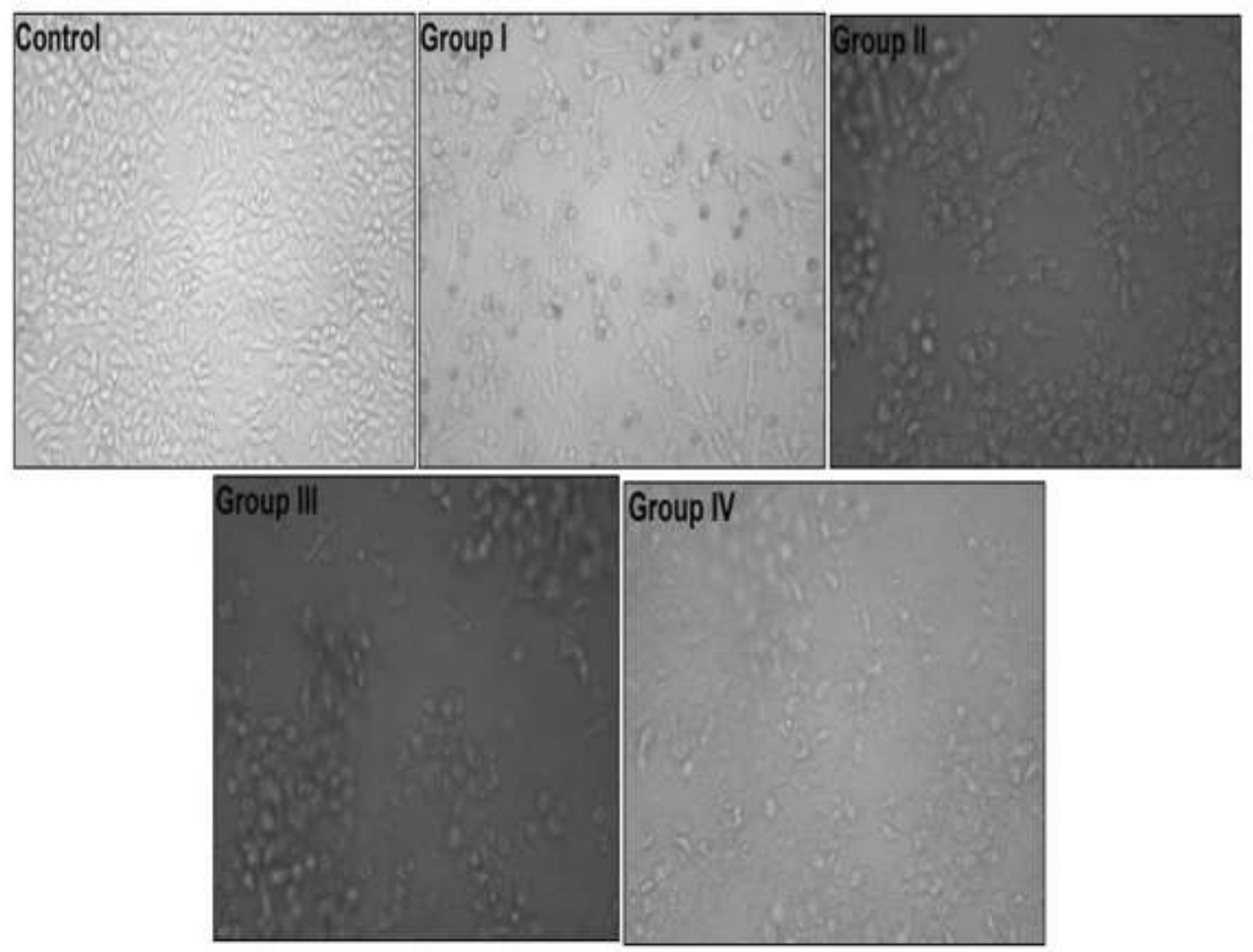

Figure 2. The effects of different concentrations of Bacillus licheniformis supernatant on PC-3 cell line during 48 hr incubation. 

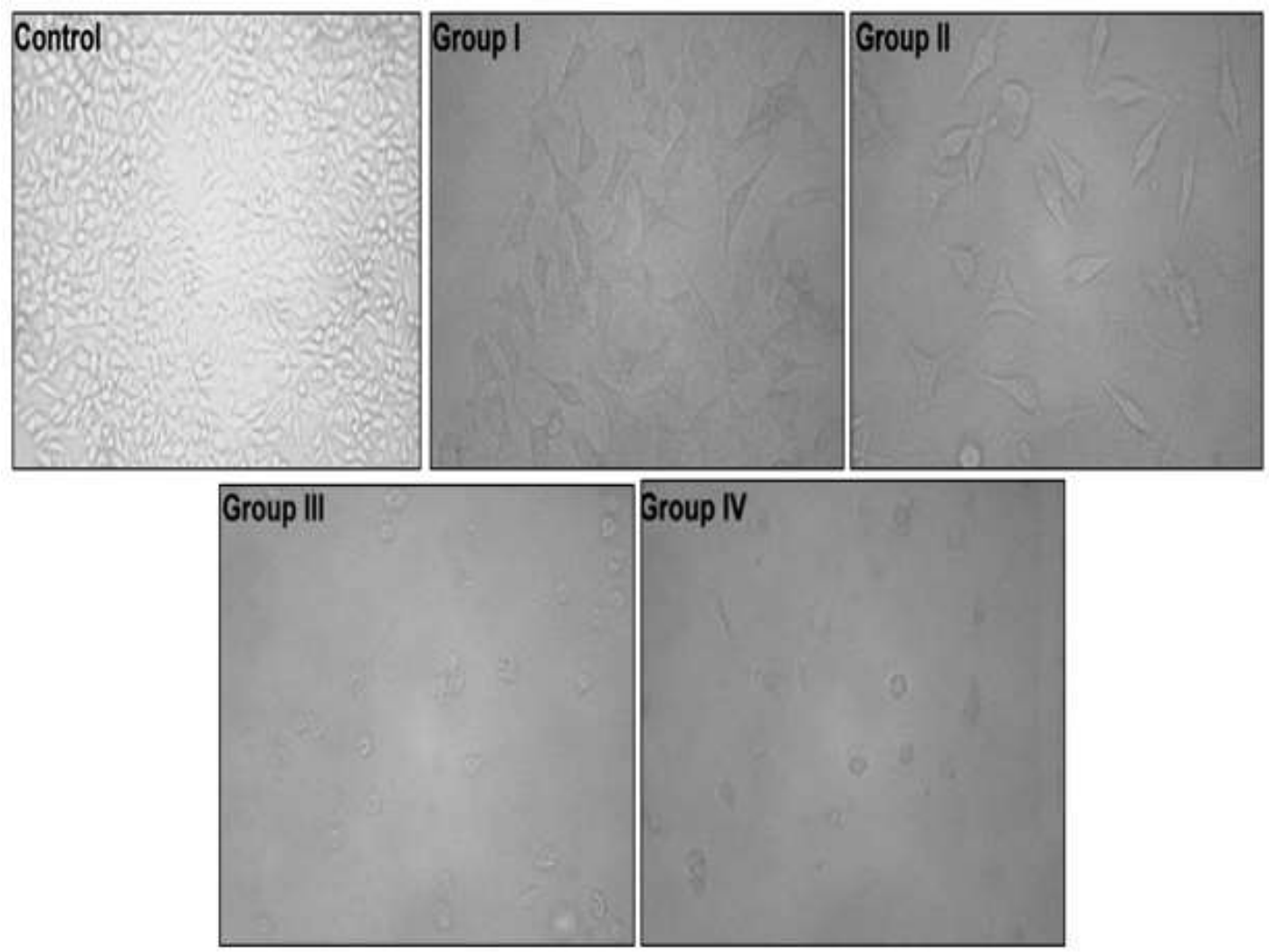

Figure 3. The effects of different concentrations of Bacillus licheniformis supernatant on PC-3 cell line during $72 \mathrm{hr}$ incubation.

The effect of different concentrations of supernatant in PC-3 cell survival was measured at 24, 48, and $72 \mathrm{hr}$ after treatment. In $24 \mathrm{hr}$ treatment, PC-3 cell viability decreased in a dosedependent manner in all groups. This decrement was significant in groups III and IV compared to the control group $(P<0.05)$ (Figure 4$)$. In $48 \mathrm{hr}$ treatment, the survival rate decreased in all groups in a dose-dependent manner. It was significant in all groups compared to the control group $(P<0.01)$ except group I (Figure 5). In $72 \mathrm{hr}$ treatment, the survival rate decreased significantly in all groups compared to the control group $(P<0.001)$ in a dosedependent manner (Figure 6).

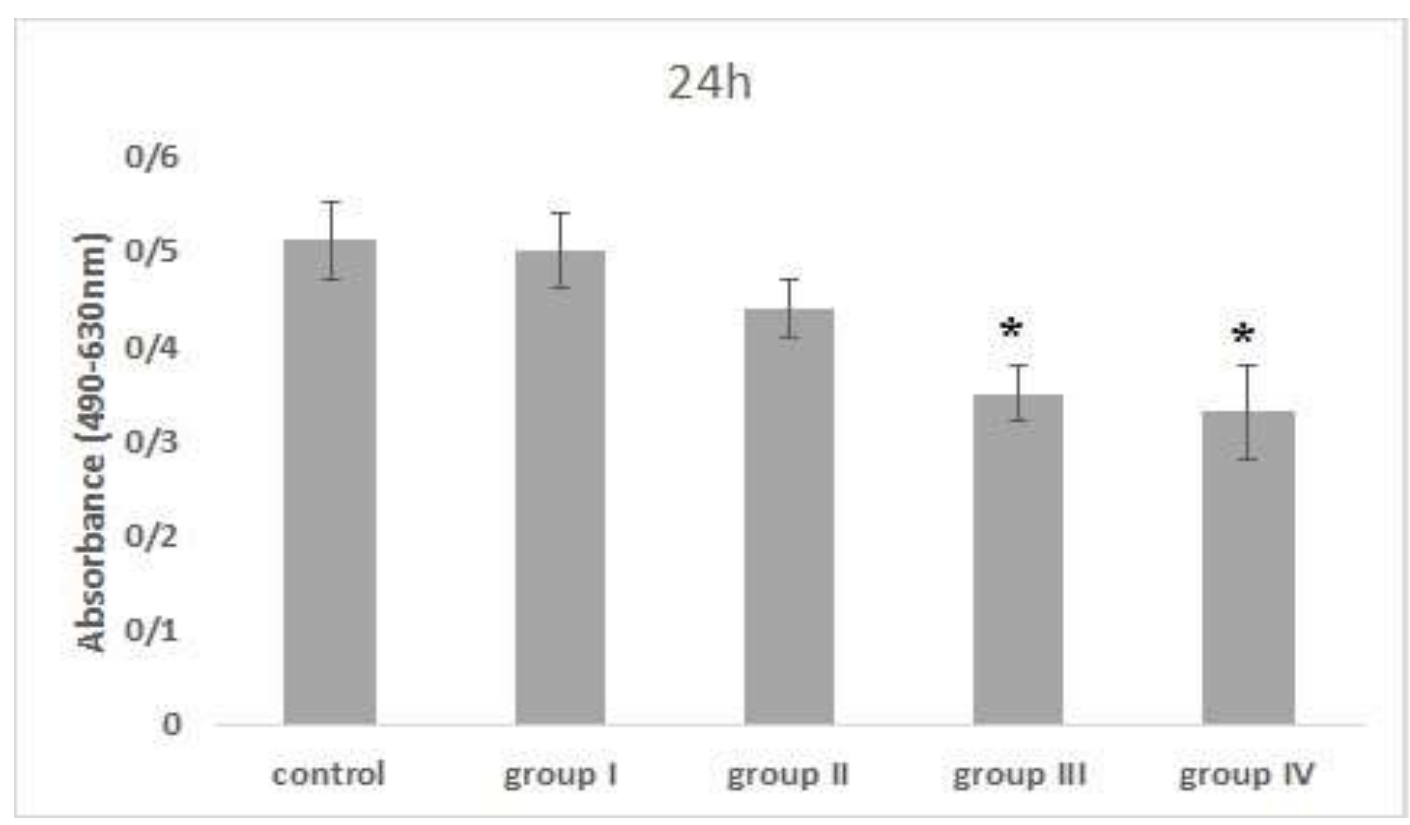

Figure 4. The effect of Bacillus licheniformis supernatant on PC-3 cell viability for 24 hr of incubation (*: P<0.05, significant difference compared to the control group). 


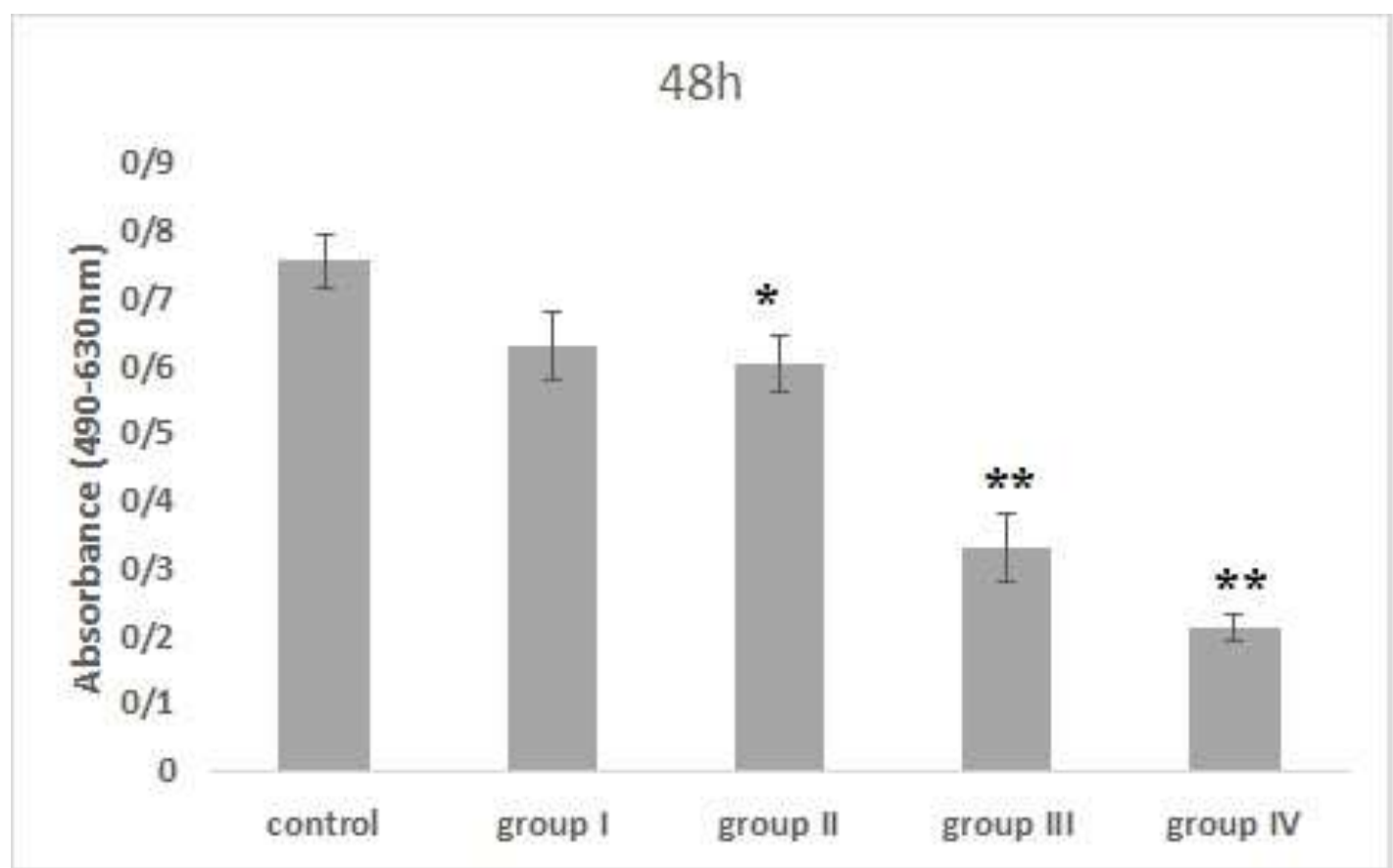

Figure 5. The effect of Bacillus licheniformis supernatant on PC- 3 cell viability for $48 \mathrm{hr}$ of incubation $\left({ }^{*}: P<0.01\right.$ and ${ }^{* *}: P<0.001$, significant and highly significant differences compared to the control group).

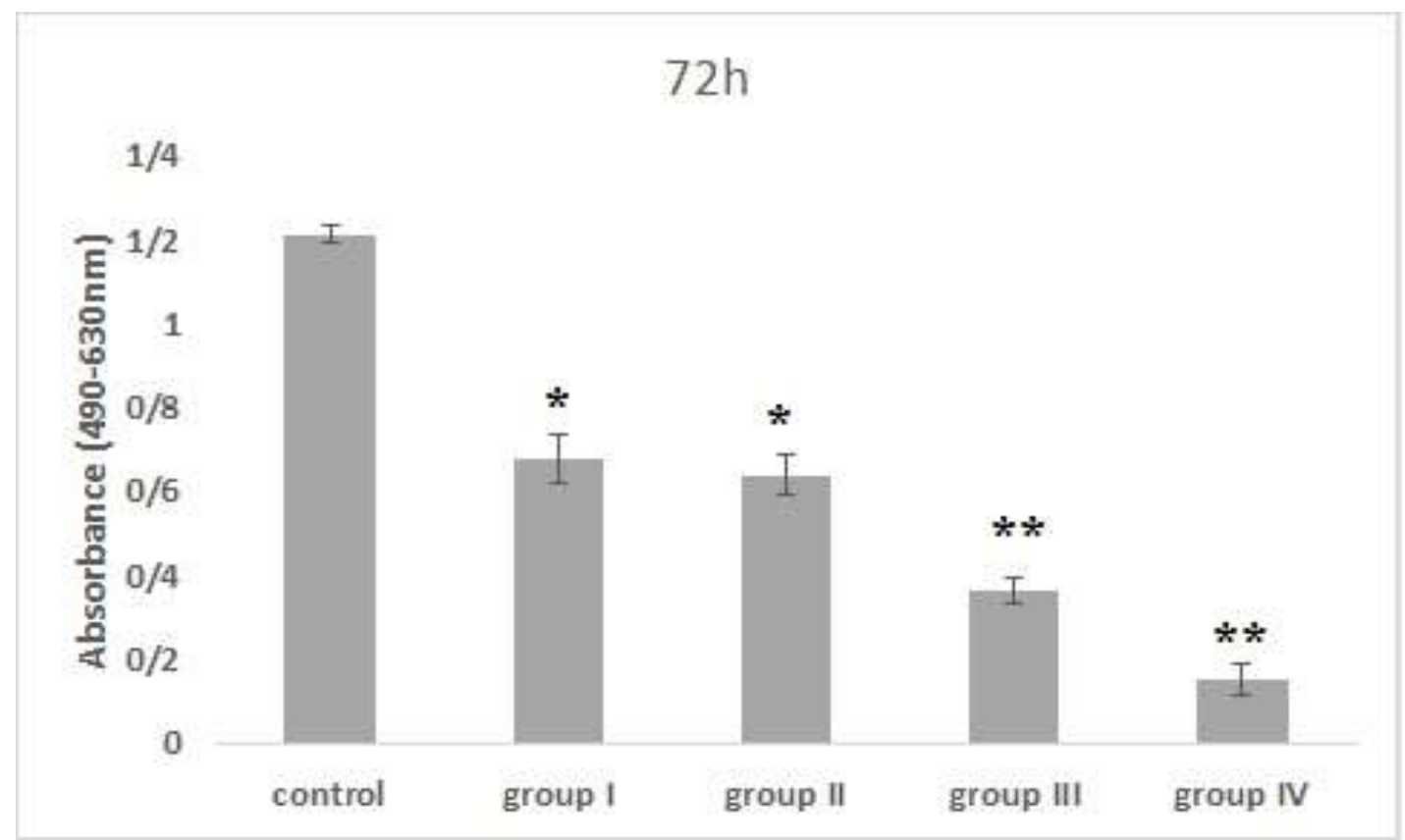

Figure 6. The effect of Bacillus licheniformis supernatant on PC-3 cell viability for $72 \mathrm{hr}$ of incubation $\left(*: P<0.01\right.$ and ${ }^{* *}: P<0.001$, significant and highly significant differences compared to the control group).

Anxin V-FITC test was used to evaluate the apoptosis. The PC-3 cells were exposed to different concentrations of supernatant for 24,48 and $72 \mathrm{hr}$ and their effect on the rate of apoptosis was measured. The results indicated an increase in the percentage of cell death in the treated experimental groups (Figures 7, 9 and 11). The percentage of viable cells in the treated groups decreased compared to the control group by increasing dose and duration of treatment. As can be seen in Figures 7, 9 and 11, the percentage of viable cells decreased in all groups at all three incubation times compared to the control group which was statistically significant. Also, the percentage of cells in the early and late stages of apoptosis increased significantly by increasing the supernatant concentrations and incubation time (Figures 8, 10 and 12). 

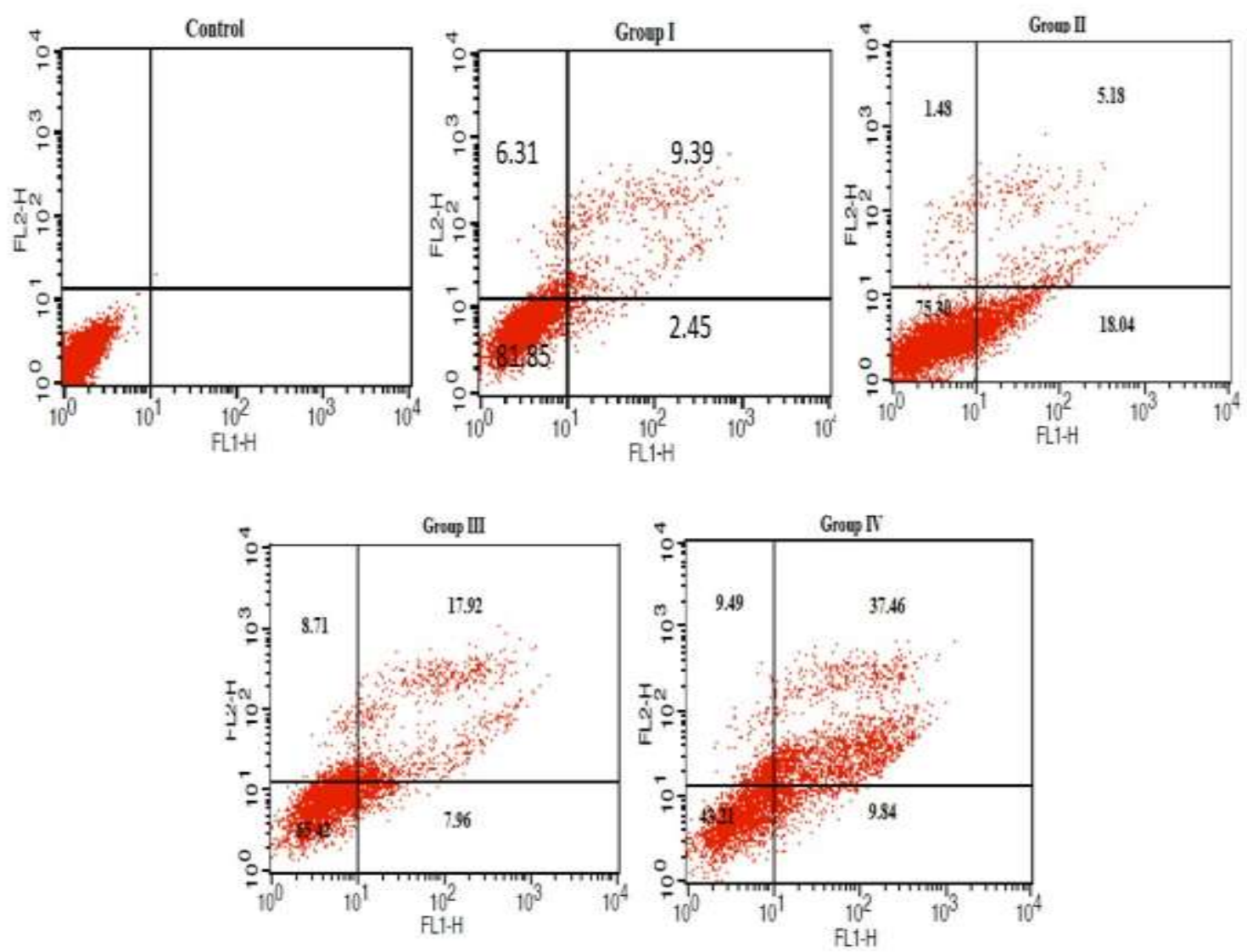

Figure 7. The effect of Bacillus licheniformis supernatant on PC-3 cells apoptosis. The PC-3 cells were incubated with $5-20 \mathrm{mg} / \mathrm{ml}$ of supernatant for $24 \mathrm{hr}$.

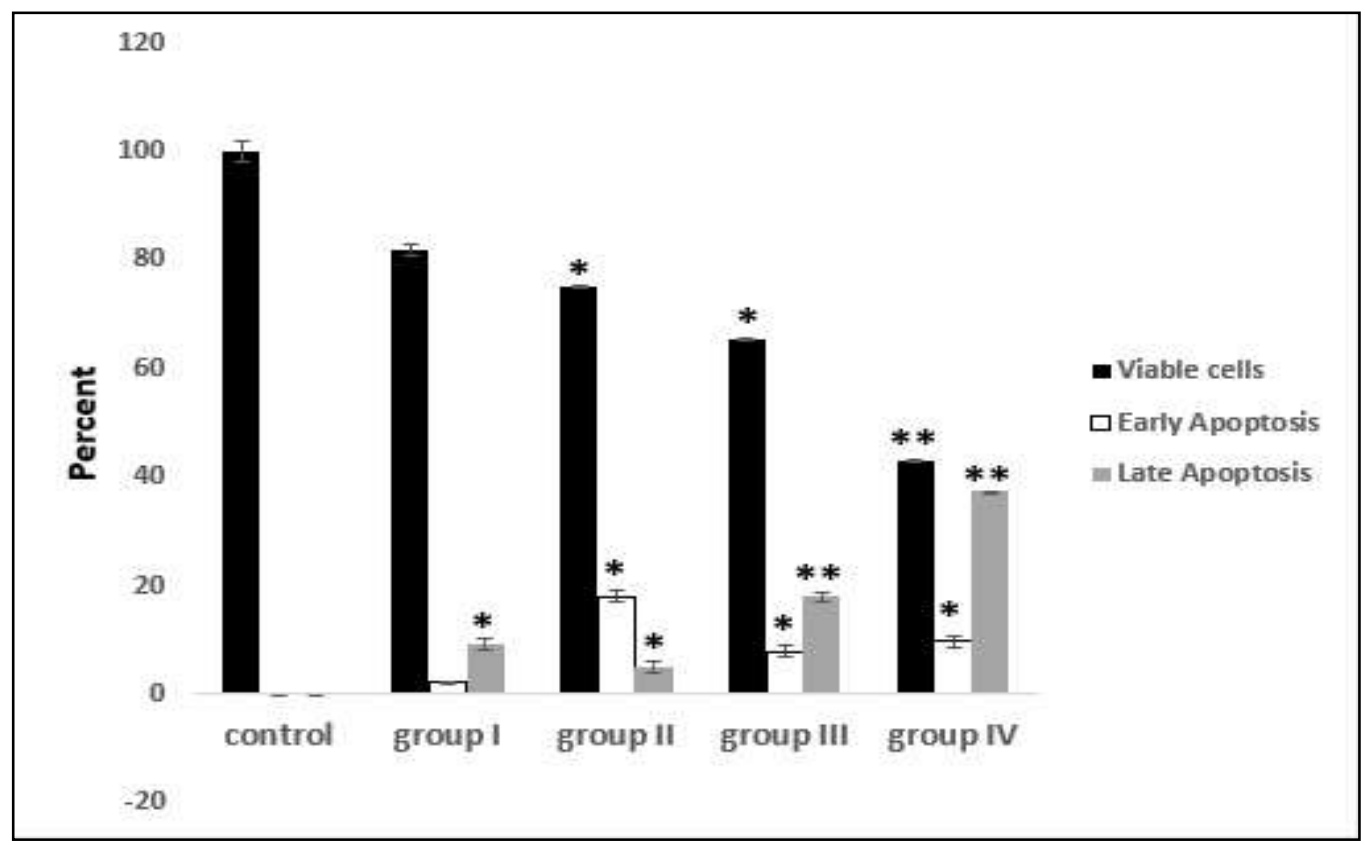

Figure 8. Percentage of viable cells, early apoptosis and late apoptosis in PC-3 cells treated with different concentrations of Bacillus licheniformis supernatant for $24 \mathrm{hr}$. *: P-value<0.05; **: P-value<0.01 vs. control group. 

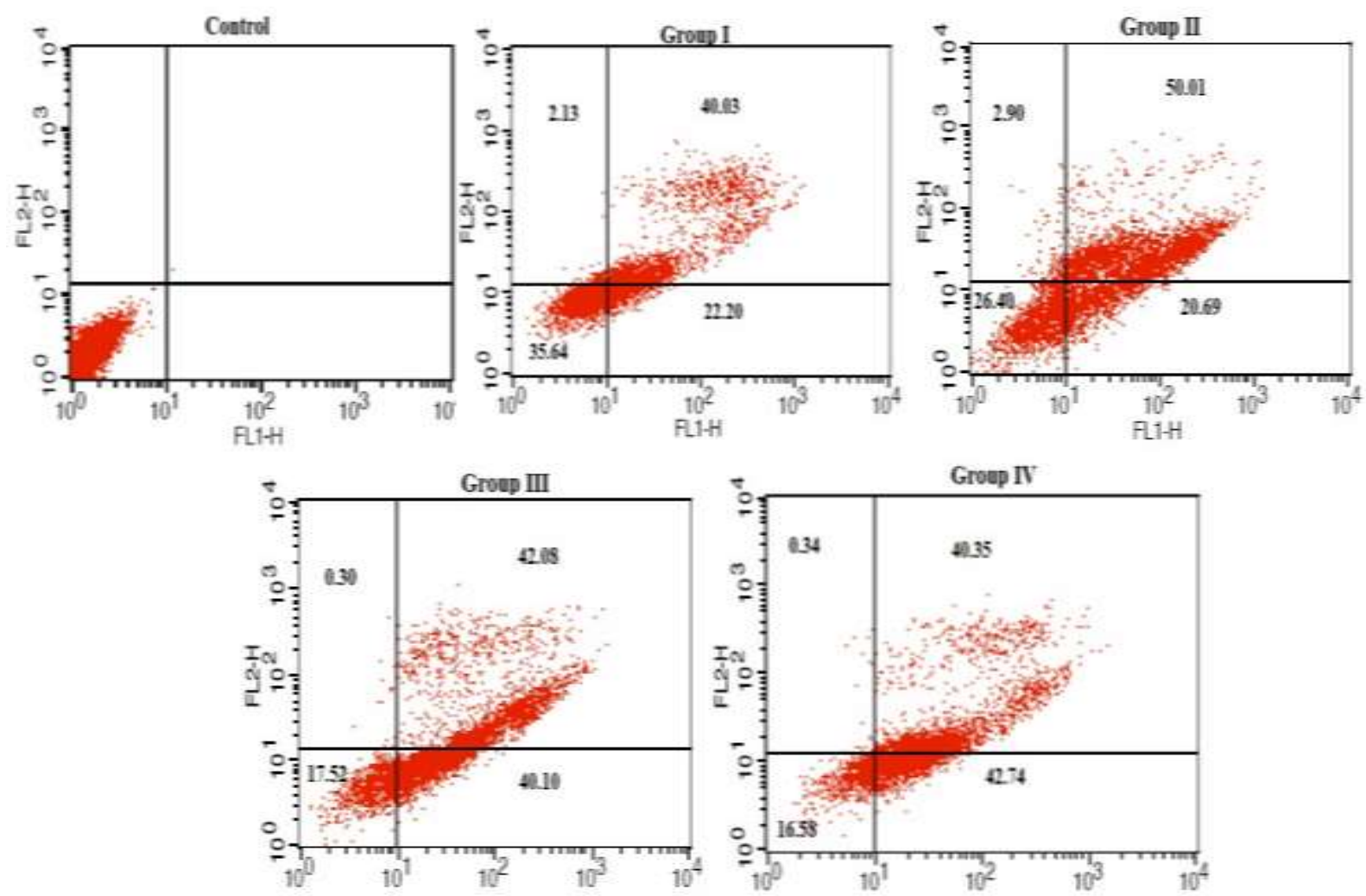

Figure 9. The effect of Bacillus licheniformis supernatant on PC-3 cells apoptosis. The PC-3 cells were incubated with $5-20 \mathrm{mg} / \mathrm{mL}$ of supernatant for $48 \mathrm{hr}$.

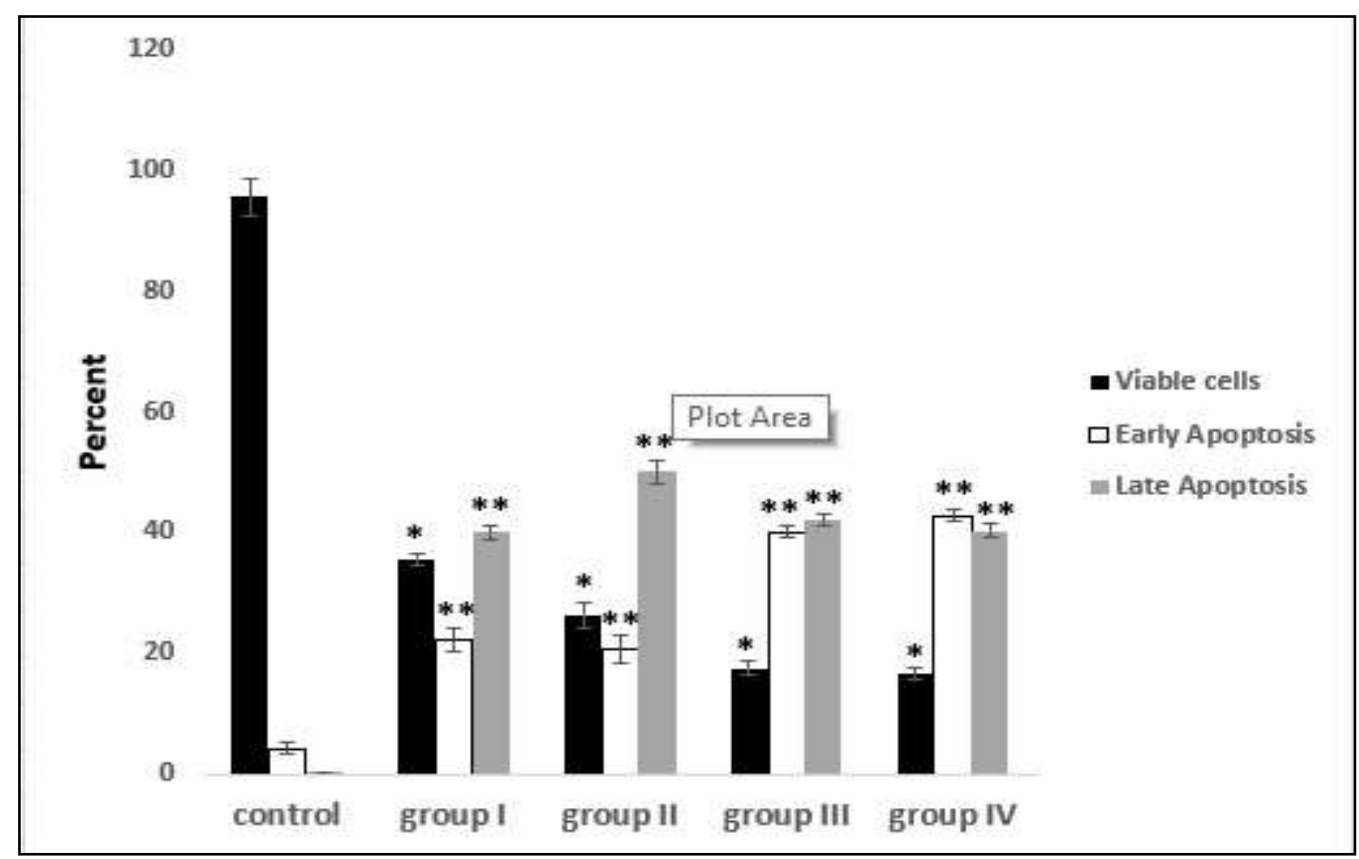

Figure 10. Percentage of viable cells, early apoptosis and late apoptosis in PC-3 cells treated with different concentrations of Bacillus licheniformis supernatant for 48 hr. *: P-value $<0.01 ; * *$ : P-value $<0.001$ vs. control group. 

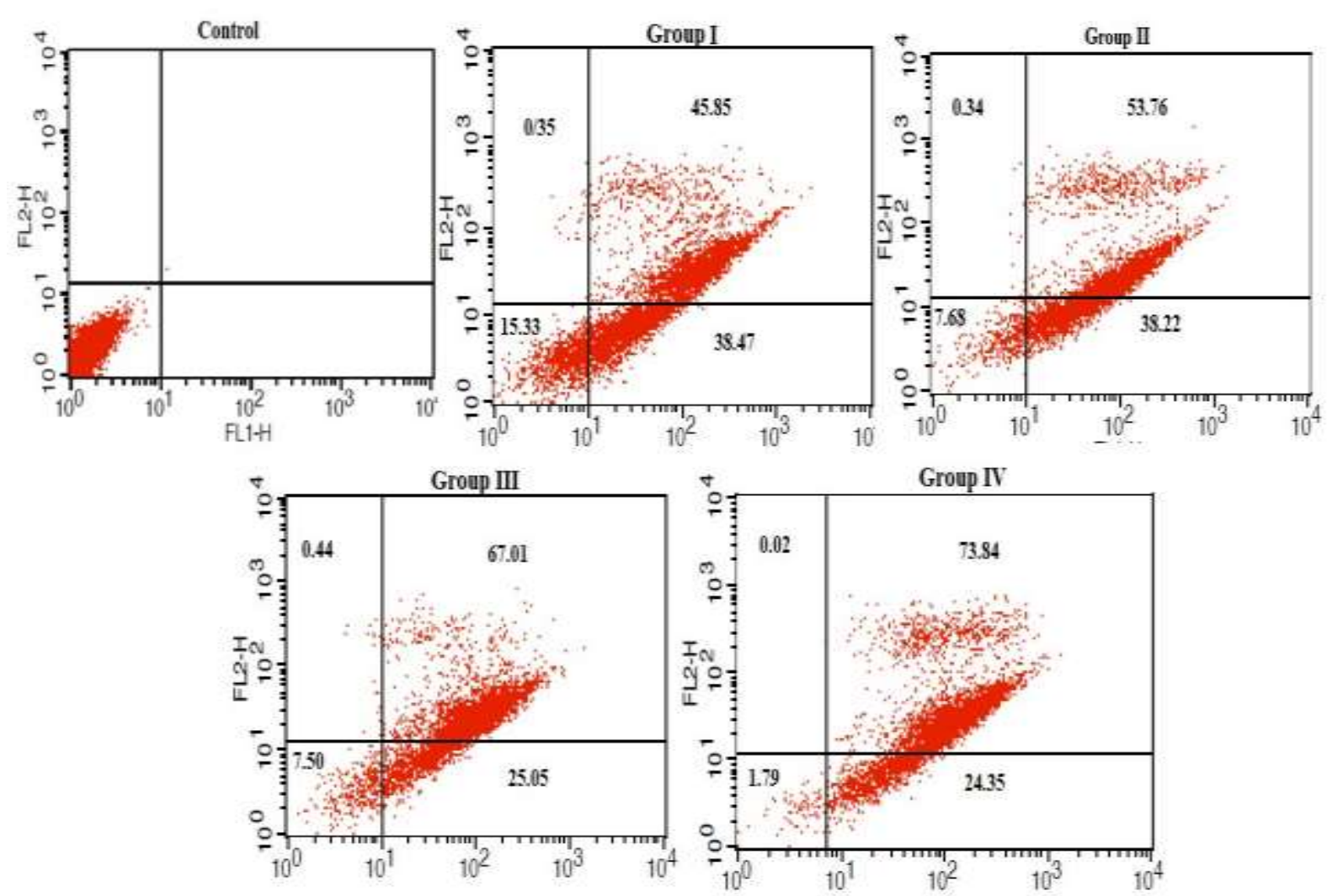

Figure 11. The effect of Bacillus licheniformis supernatant on PC-3 cells apoptosis. The PC-3 cells were incubated with $5-20 \mathrm{mg} / \mathrm{mL}$ of supernatant for $72 \mathrm{hr}$.

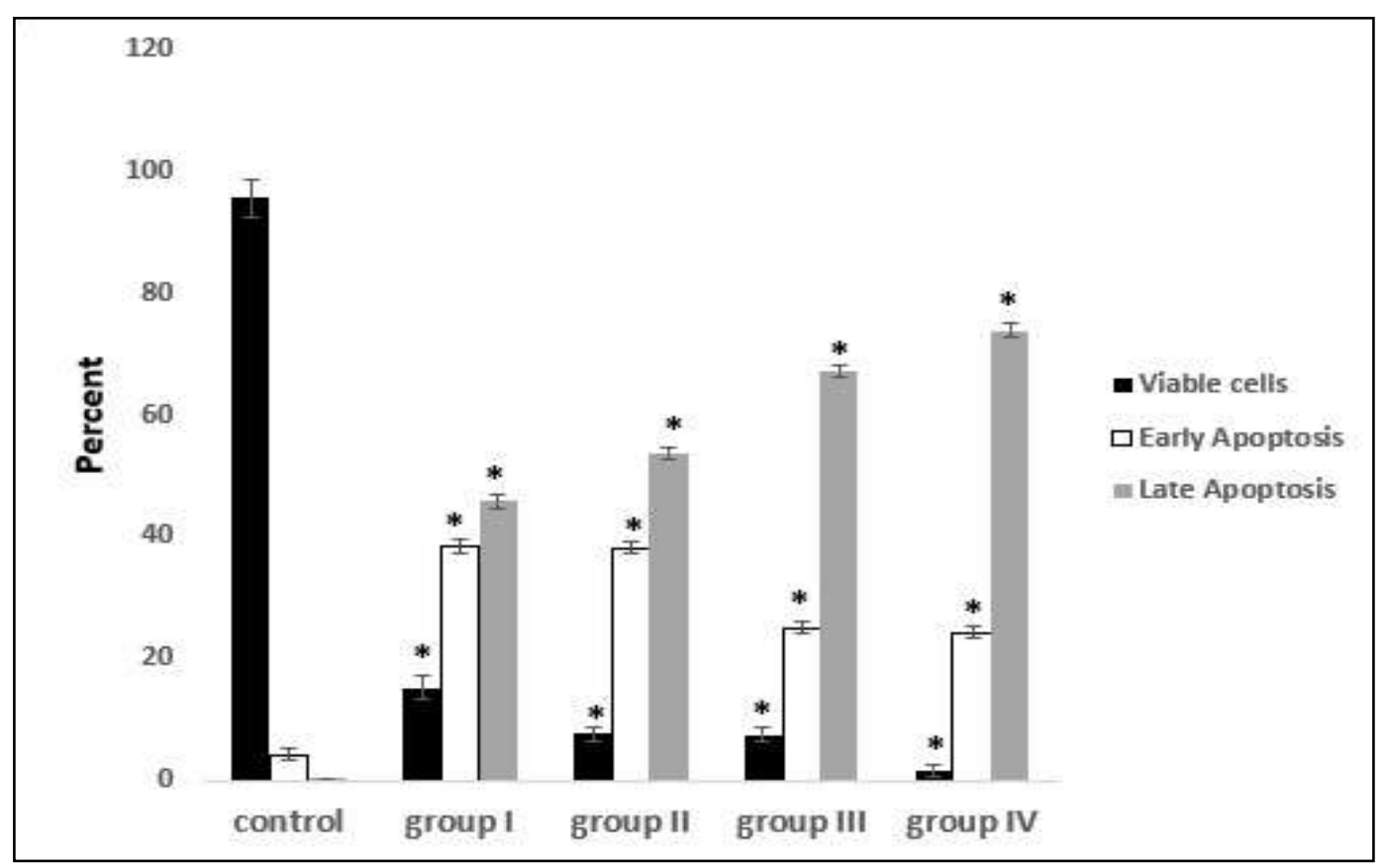

Figure 12. Percentage of viable cells, early apoptosis and late apoptosis in PC-3 cells treated with different concentrations of Bacillus licheniformis supernatant for $72 \mathrm{hr}$. *: P-value $<0.001$ vs. control group. 


\section{Discussion}

Due to the spread of cancer as one of the most important and common causes of human mortality, resistance to chemotherapy drugs and several disadvantages and sometimes oncogenic harms of these drugs, the necessity to discover new compounds and create independency from foreign countries in the field of antibiotics production and anti-cancer drugs is felt. On the other hand, due to the fact that rare studies have been conducted in the field of antitumor compounds production from endemic bacteria of Iran, there is a need to identify new endemic strains producing new compounds. Also, the ability to produce antimicrobial substances is not only a defense tool, but also from a pharmacological point of view and due to the side effects of antibiotics and resistance of pathogenic microorganisms against antibiotics, they can be used effectively in the treatment of diseases. Therefore, this study investigated the anti-cancer effects of Bacillus licheniformis products against prostate cancer cell line (PC-3) by cytotoxicity assay. In this study, Bacillus licheniformis was used as the best isolate in terms of antimicrobial compounds production with a wide range of effects to study anti-cancer activity and the effect of its compounds was investigated on PC-3 cell line viability.

The PC-3 cell line was treated with Bacillus licheniformis supernatants in 4 groups. The results of MTS assay in $24 \mathrm{hr}$ incubation with the treatment showed that cell viability was dose-dependent, so that, with increasing the concentration, the cell viability decreased compared to the control group. This decrement was significant in groups III and IV compared to the control group $(P<0.05)$. Also, in the $48 \mathrm{hr}$ treatment, all groups except the first group showed significant differences from the control group $(P<0.01)$ and finally the cells treated for $72 \mathrm{hr}$, showed a dose-dependent decrease in all groups compared to the control group. It was significant in all groups compared to the control group $(P<0.001)$.

Phonnok et al. in 2010 investigated microbial metabolites and their role in the apoptosis induction in cancer cells. They evaluated the effect of 394 microbial extracts on the proliferative activity of 4 categories of cancer cells using MTT assay. Using these extracts, morphological changes such as cell shrinkage, loss of surface contact and loss of cell swelling were observed in all treated cancer cells (15), which can confirm the results of the current study. The cell viabilities showed a concentration-dependent decrease compared to the control group when exposed to different concentrations of supernatant for 24, 48 and $72 \mathrm{hr}$.

In 2010, Tuo et al. tested the anti-proliferative effect of 7 wild Lactobacillus strains isolated from food fermentation on HT-29 cell line isolated from laboratory models. The results showed that only Lactobacillus coryniformis strain had antiproliferative activity on HT-29 cells (19). In the present study, different concentrations of Bacillus licheniformis supernatant were able to inhibit the PC3 cell line growth.

Moosavi et al. in 2011 investigated the effect of the secondary metabolites form Streptomyces sp. ABRIINW 111 on K562 cell apoptosis. In their study, K562 cell was treated with different concentrations of ether-soluble metabolites for 12 to $72 \mathrm{hr}$. Trypan blue dye and DNA fragmentation test were used to investigate the growth inhibition and apoptosis occurrence, respectively. The data showed that ethersoluble metabolites inhibited the growth of K562 cell line in a concentration- and time-dependent manner (20). The current study has presented similar results to Mousavi's study in terms of examining the effect of produced compounds on cancer cell line and apoptosis. In addition, Annexin kit and flow cytometry method were used in the present study.

In a 2013 study, Parsaseresht et al. examined the effect of Lactobacillus rhamnosus GG secondary metabolites on Cacoll cancer cell (colorectal cancer cell line) and showed that, Lactobacillus rhamnosus GG metabolites inhibited Cacoll cancer cell growth at concentrations of 100, 200 and $300 \mathrm{mg} / \mathrm{mL}$ by $60.8 \%, 72.5 \%$ and $82.1 \%$, respectively (16). These findings are in line with the findings of the present study on the anti-cancer effects of microbial compounds. In 2013, Mahmoudi Aslzadeh et al. examined the probiotic effect of Bifidobacterium bifidium on Cacoll cancer cells. To this purpose, 100, 200 and $300 \mu \mathrm{L}$ of the supernatants were applied to the Cacoll cancer cells cultured in 96-well microplates. The results showed inhibitory percentage of Bifidobacterium supernatant on cancer cells at $55 \%$ to $82 \%$, which were related to the concentration of $100 \mu \mathrm{L}$ in $24 \mathrm{hr}$ and 300 $\mu \mathrm{L}$ in $72 \mathrm{hr}$, respectively (21). In this study, selective bacterial supernatant was used and similar results were obtained.

In 2014, Vijaya Kumar et al. examined the effect of metabolites of Bacillus cereus and Bacillus popilliae isolated from the infected specimens in Shimoga, Karnataka, India, to investigate the anti-cancer and cytotoxic properties of various components. The extracts obtained from the metabolites of these two bacteria were used on normal human liver cells and 2 types of cancer cells. The results indicated that both samples had significant activity. However, the sample taken from Bacillus cereus showed a high cytotoxic effect, but the metabolites of Bacillus popilliae had toxic effects on normal and cancer cells (22). These results are similar to the present research, except that 
in the present study no toxic effects were observed on normal cells.

In 2015, Vazquez-Rivera et al. in Mexico investigated the cytotoxic effects of the dipeptide cycle of Pseudomonas aeruginosa PAO1 on apoptosis in human cancer cell lines. These compounds showed $50 \%$ inhibitory effect (23), which confirms the results obtained in the current study.

Pasiar et al. in 2016 studied the selective growth inhibition of the breast adenocarcinoma cell line using metabolites produced by the endemic strain Pseudomonas UW4 sp. in the laboratory. In this study, the antimicrobial activity of the metabolites of the endemic strain Pseudomonas UW4 sp. was investigated against some pathogenic bacteria. To evaluate the anti-cancer activity, SKBR3 and HU-02 cells were treated with different concentrations of 5 , 10, 15 and $20 \mathrm{mg} / \mathrm{mL}$ for 24, 48 and $72 \mathrm{hr}$. The obtained results showed that Pseudomonas UW4 sp. was able to produce antimicrobial metabolites against Staphylococcus aureus. Metabolite treatment showed that by increasing the concentration in a dose- and time-dependent manner, the viability of the cells decreased. The maximum effect was related to 20 $\mathrm{mg} / \mathrm{ml}$ concentration at $72 \mathrm{hr}$ treatment. While metabolites at different concentrations did not have a significant effect on normal fibroblasts (18), these results confirmed the present study results.

Zhang et al. in 2017 examined the antitumor property of Rhodococcus sp. Lut0910 isolated from contaminated soil. The effects of those metabolites were investigated on two categories of liver cancer cells (HepG2) and uterine cancer cells (Hela). Treatment of these cancer cells with the bacterium Rhodococcus Lut0910 extract delayed cell proliferation in a dose-dependent pattern. Also, oral administration of the mentioned bacterial extract to the mice with specific tumors resulted in inhibition of the tumor growth in comparison with the control group (1). This study outcome in the field of cytotoxic effects of microbial production compounds was in line with the present study.

Dehnad et al. in 2017 investigated antimicrobial, chemical and histopathological properties of the secondary metabolites of Streptomyces levis isolated from the soils in the Northwest of Iran in in-vitro and in-vivo conditions. Their data showed that only the ether metabolite had effect on all gram-positive and gram-negative microbial strains. The histopathological examination results showed that the bacterial metabolite has a significant healing effect on Staphylococcus aureus wound. The antimicrobial and antitumor activities can be due to the presence of 1,2Benzenedicarboxylic acid diisooctyl ester and bis (2ethylhexyl) phthalate in the metabolite composition (24), which were in line with the present study findings on the anti-cancer effects of the microbial compounds.

\section{Conclusion}

The results of MTS and annexin tests showed that the rate of apoptosis in PC-3 cell line increased significantly by increasing the concentration of Bacillus licheniformis supernatant. Considering that cell proliferation and irregular apoptosis are the characteristics of cancer cells, Bacillus licheniformis supernatant can be used to reduce cell proliferation and increase apoptosis for the prevention and treatment of prostate cancer.

\section{Acknowledgment}

We would like to express our gratitude and thanks to all those who helped us during the implementation of this research. It is worth mentioning that this article is the result of a part of the Ph.D thesis of Mr. Ahmadreza Shahniani from the Islamic Azad University, Kazerun Branch. This article was financially supported by the authors.

\section{Ethical considerations}

Ethical issues (Including plagiarism, informed consent, misconduct, data fabrication and/or falsification, double publication and/or submission, redundancy, etc.) have been completely observed by the authors.

\section{Funding and support}

This research resulted from an independent research without receiving any financial support.

\section{Conflict of Interest}

Authors declared no conflict of interest. 


$$
\begin{aligned}
& \text { مجله ميكروبشناسى يزشكى ايران }
\end{aligned}
$$

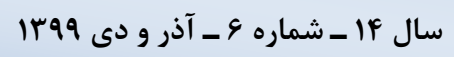

القاء آيويتوزيس در سلولهاى سرطان بِروستات (PC-3) با استفاده از سو يِرناتانت

\title{
Bacillus licheniformis
}

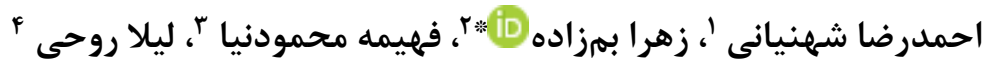

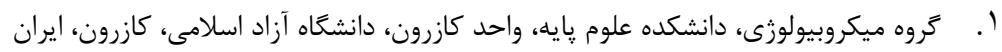

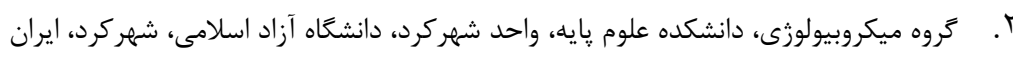

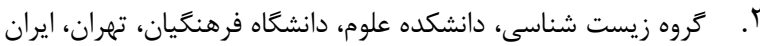

\begin{tabular}{|c|c|}
\hline جكبيده & اطلاعات مقاله \\
\hline 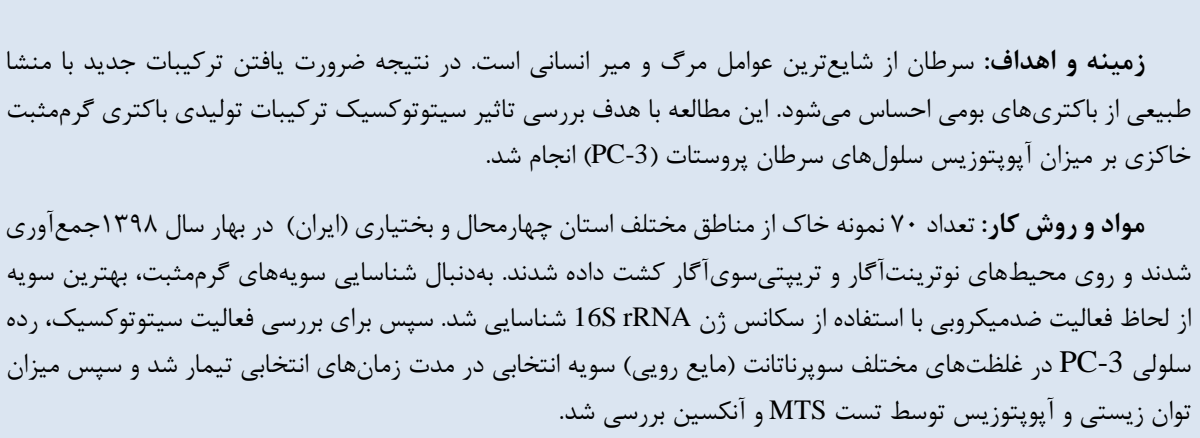 & 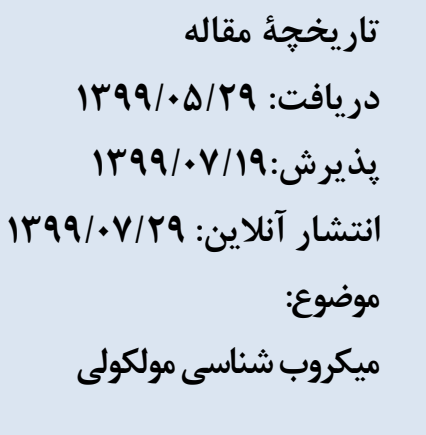 \\
\hline 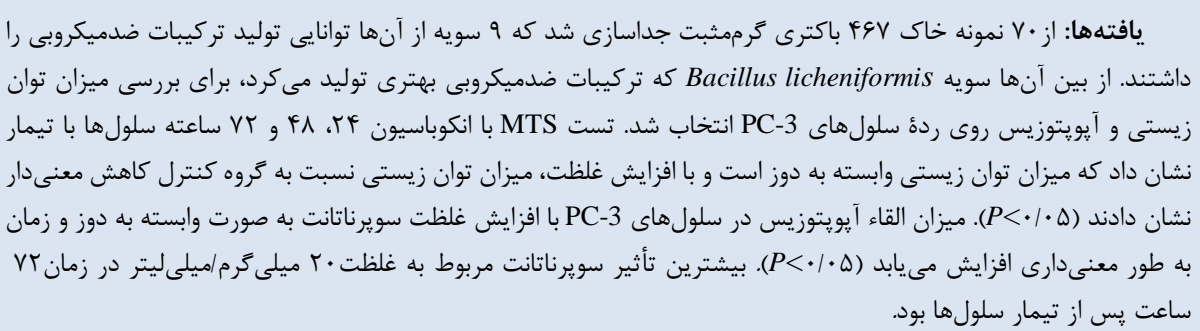 & 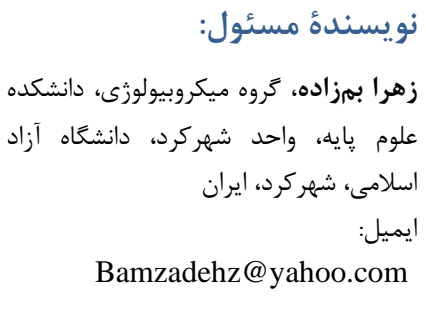 \\
\hline يرداخت. & \\
\hline ، ميكروب شناسى يزشكى ايران: دسترسى & \\
\hline
\end{tabular}

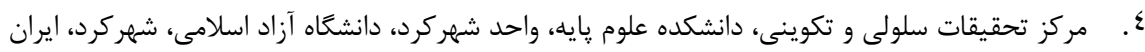

مقدمه

نفر در سال • • • ب برسد كه اين به دليل رشد قابل توجه جمعيت مسن در جهان، تغيير سبك زندگى و تغييرات اقتصادى در جامعه است ((). بلهورى كه در كشورهاى توسعهيافته، سرطان يروستات دومين

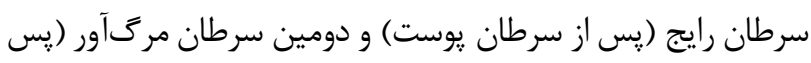

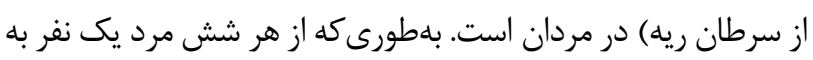

امروزه سرطان يكى از مهمترين جالشهاى سلامتى در جهان بوده و هr درصد مرت و مير در آمريكا به دليل بروز سرطان است.

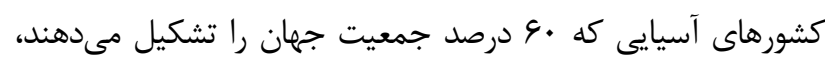

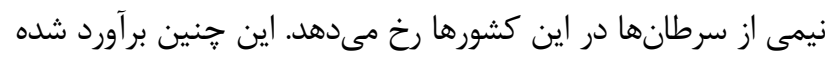

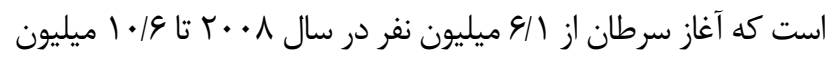


تشخيص و غربال

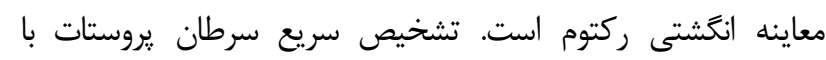

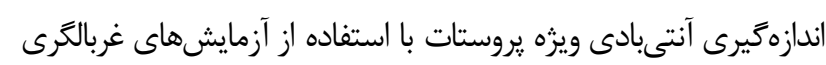

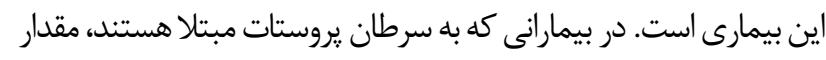

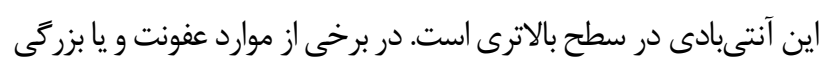
خوشخيم حجم غده يروستات مىتواند سبب افزايش ميزان - Prostate

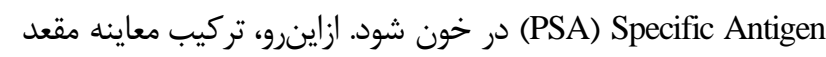
توأم با تعيين سطح PSA در خون روش دقيقترى براى تشخيص سرطان

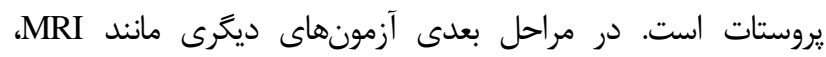

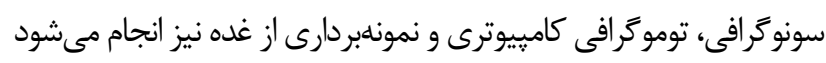

راهكارهاى مرسوم درمانى سرطان يروستات عبارتند از: جراحى

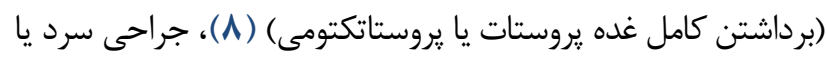

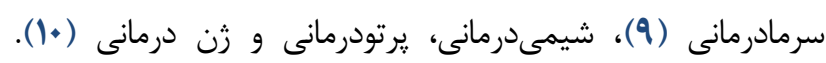

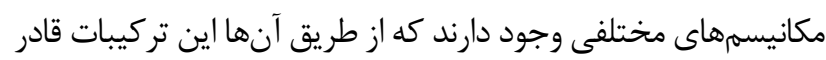

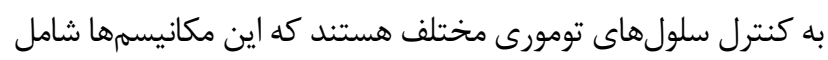

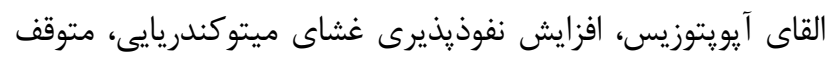

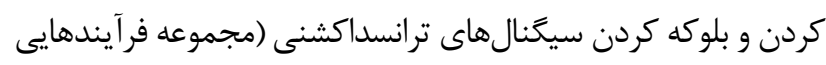

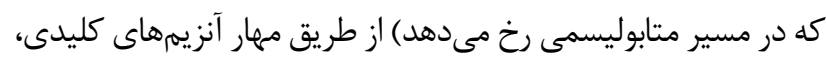

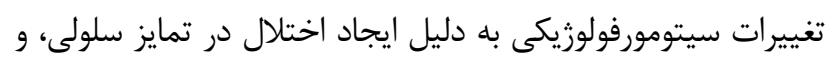

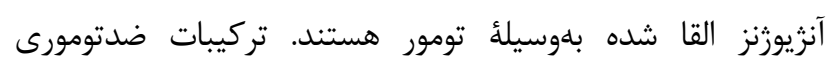

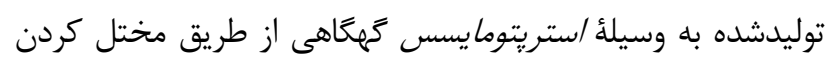

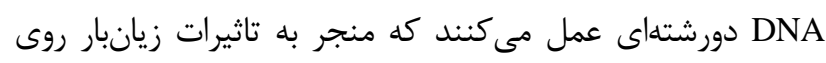

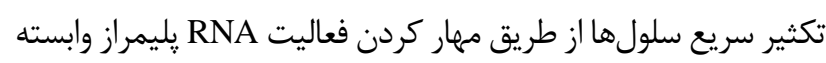

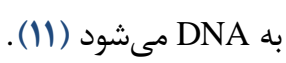

در نهايت، صرفنظر از اينكه روشهاى مختلفى براى درمان

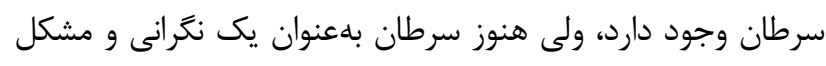

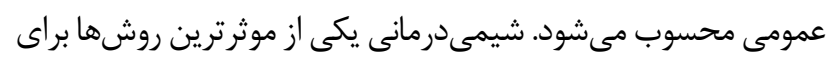

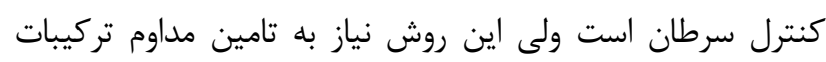

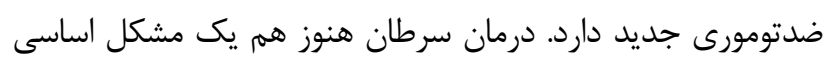

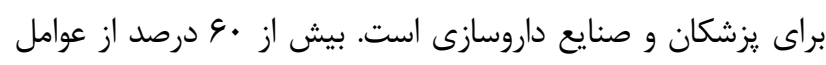

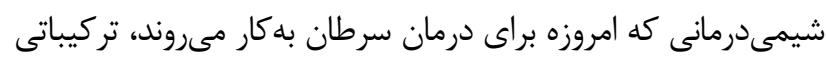

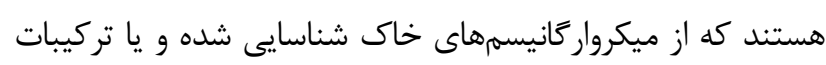

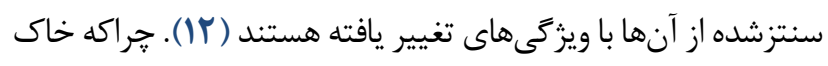

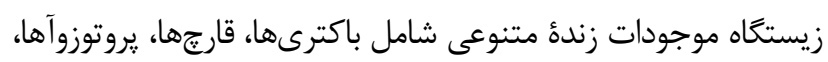

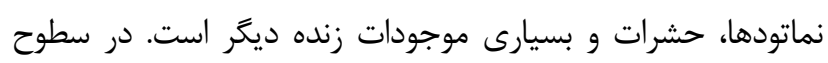

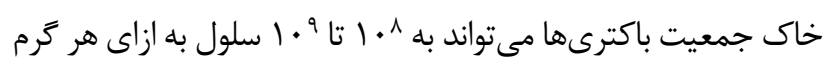

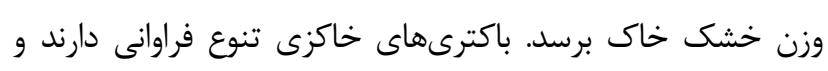

سرطان يروستات مبتلا مىشود. مطالعات إيدميولوزى نيز نشان

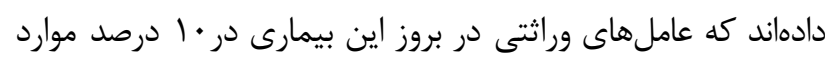

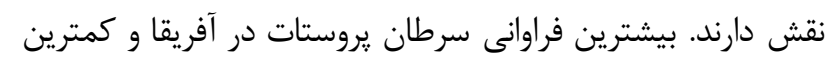

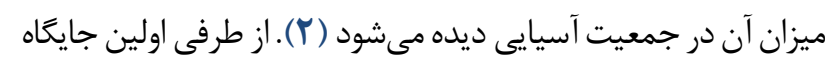
زنى كه در ارتباط با سرطان يروستات شناخته شد، جائ دايخاه

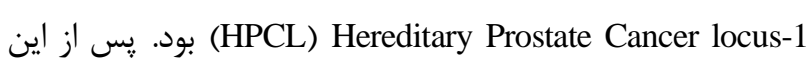
كشف جندين رن نامزد ديخر هم شناخته شدهاند، اكرجه بيشتر آنها

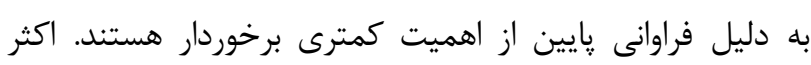

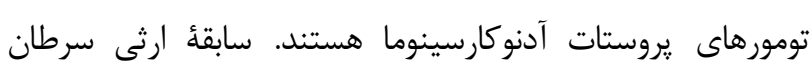

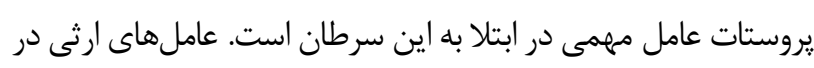

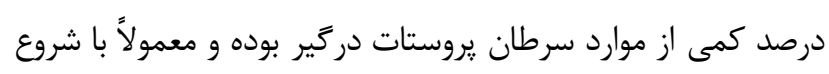

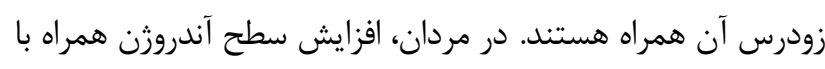

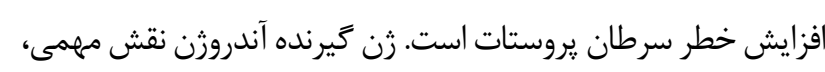

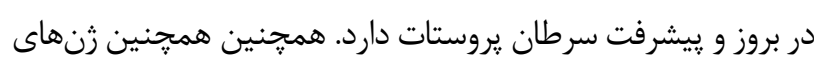
AR و ARD AR

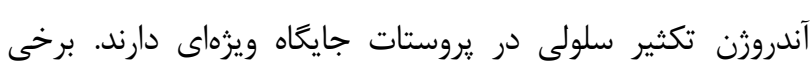

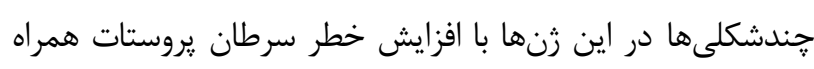

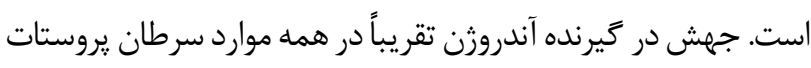

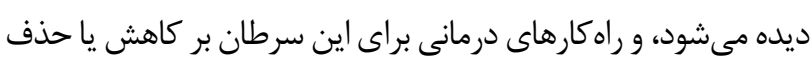

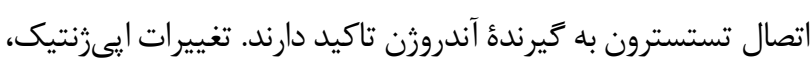

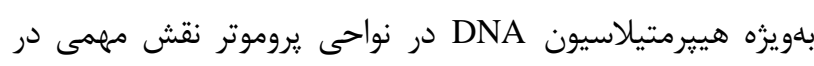

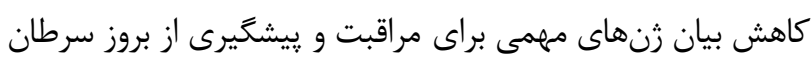

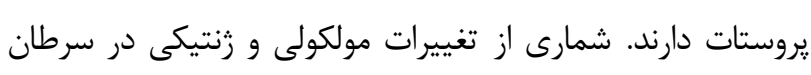

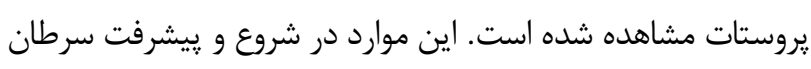
يروستات نقش دارند. زنهاى مهار كننده متاستاز هم در مر سرطان

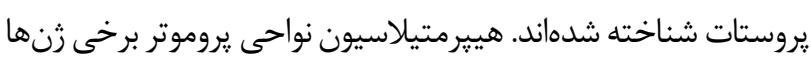

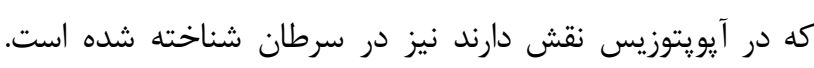

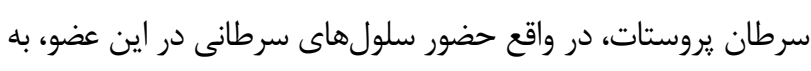

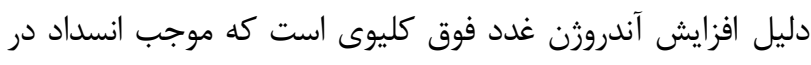

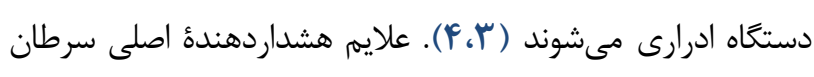

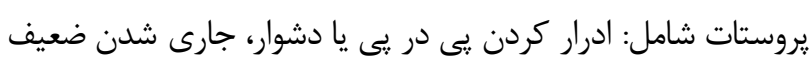

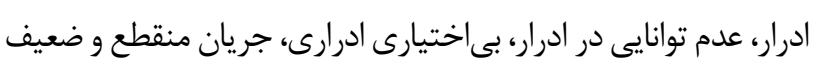

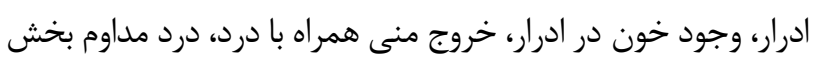

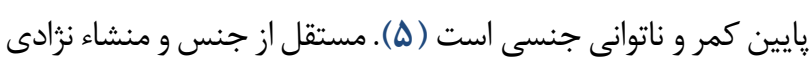

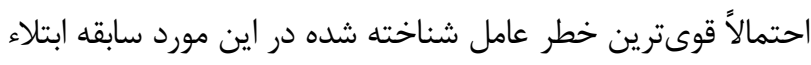

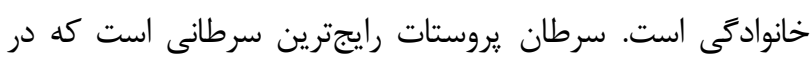

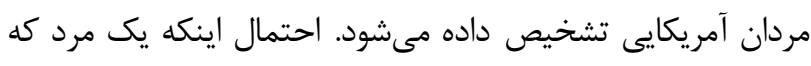

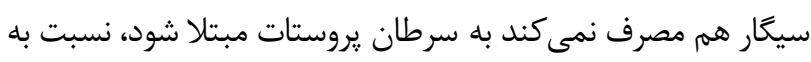

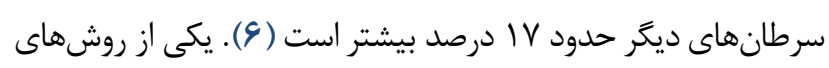


يروستات (PC-3) مورد بررسى قرار گرفته است.

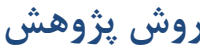

مطالعه حاضر مقطعى-توصيفى است كه معيار ورود سويرناتانت Bacillus licheniformis و معيار خروجى اثر سويرناتانت بر القاى آيويتوزيس در سلولهاى سرطان يروستات (PC-3) است.

جداسازى و شناسايى باكترى هاى كرممثبت از نمونههاى خاك در اين مطالعه·V نمونه خاك از مناطق مختلف استان

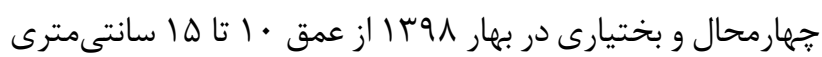

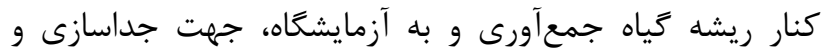
شناسايى باكترىهاى كرممثبت انتقال داده شد (IF). به دنبال

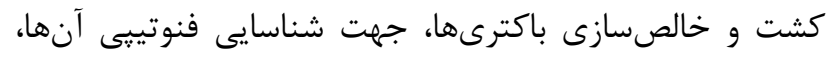

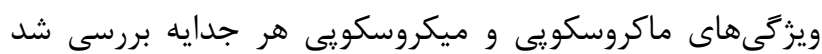

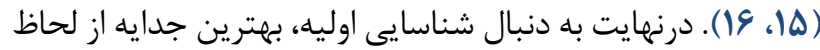
توليد تركيبات ضد ميكروبى با طيف اثر گستردهتر، با استفاده از روش شناسايى مولكولى تعيين هويت كرديد.

شناسايى مولكولى باكترى ترممثبت توليدكننده

تركيبات ضد ميكروبى

جهت شناسايى زنوتييى از سكانس زن 16S rRNA استفاده

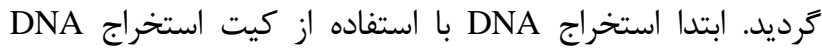

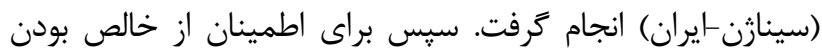

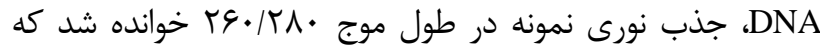

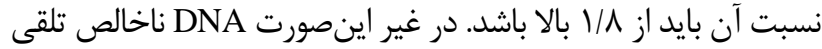

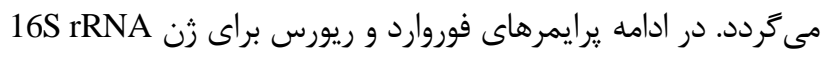
توسط شركت سينارن ايران تهيه شد (جدول (1).

كرده و نهايتا فرايند PCR توسط دستخاه ترمال سيكلر (إندورف-

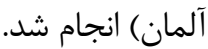

در اين تكنيك براى آغاز فرآيند يلى مريزاسيون دستگاه

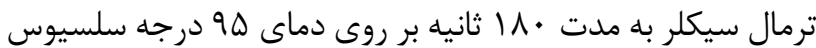

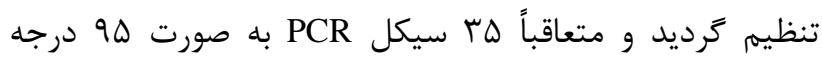

مىتوانند هوازى، بىهوازى و يا بىهوازى اختيارى باشند. علاوه بر اين،

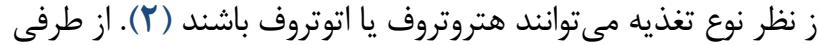
مطالعات نشان داده است كه خاك و منطقه ريزوسفر حاوى هزاران

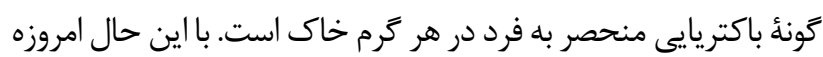
تنها بخش بسيار كمى از اين باكترىهايى كه قادر به توليد متابوليتهاى ثانويأ زيستى هستند، كشت و مطالعه شدهاند. مطالعات نشان داده است كه حتى سويههايى از باكترىها قادر به توليد طيف

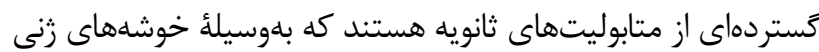
كد مىشوند كه اين زنها در شرايط آزمايشعاهى بيان نمى

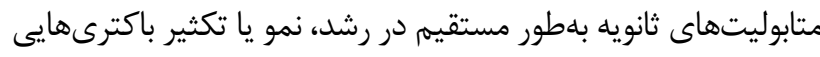

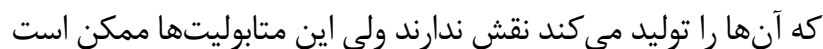
نقشهاى اكولوزيكى در ميانكنش باكترىهاى توليدكننده آنها با

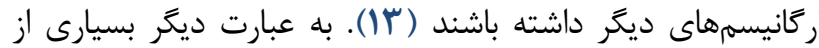
متابوليتهاى ميكروبى داروهاى ضرورى براى درمان سرطان هستند.

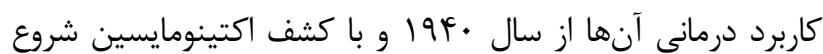
شده و از آن يس تركيبات جديد زيادى با ويزگى هاى ضد سرطانى از إنا منابع طبيعى شناسايى و جداسازى شده اند (r (ا). در نهايت با توجه به كسترش شايع و روزافزون سرطان كه يكى از مهمترين و شايعترين عوامل مرك و ميرانسانى است، نياز براى كشف تركيبات جديد و ايجاد استقلال در زمينه توليد متابوليتهاى ضد سرطانى و عدم وابستخى به كشورهاى بيخانه احساس مى شیود. از طرفى از آنجا كه تاكنون مطالعات كمى در زمينه تاثير متابوليتهاى بـاى توليدى ميكروبى بر روى سلولهاى سرطانى صورت گرفته است و نيز

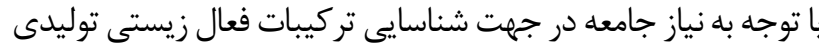
جديد توسط باكترىهاى بومى، لذا در اين تحقيق اثرات ضدسرطانى

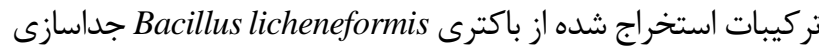
شده از خاك استان جهارمحال و بختيارى عليه رده سلولى سرطان

جدول ا. توالى يرايمرهاى فوروارد و ريورس براى ثن 16s rRNA (IV)

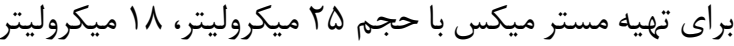

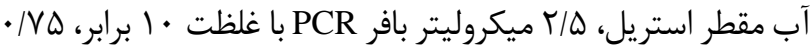

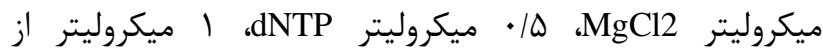

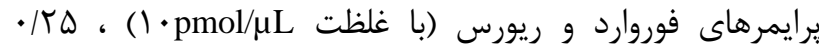
ميكروليتر از آنزيم يلىمراز و ا ميكروليتر از DNA الكو را مخلوط 
كروه I: سلولها در معرض غلظت ه ميلى گرم/ميلىليتر سويرناتانت Bacillus licheniformis قرار گرفتند. گروه II سلولها در معرض غلظت • ا ميلى گرم/ميلىليتر سويرناتانت Bacillus licheniformis قرار كرفتند. كروه III سلولها در معرض غلظت ها ميلى سويرناتانت Bacillus licheniformis قرار كرفتند. كروه IV: سلولها در معرض غلظت · · ميلى گرم/ميلىليتر سويرناتانت Bacillus licheniformis قرار كرفتند.

كروه كنترل: سلولها در معرض محيط كشت

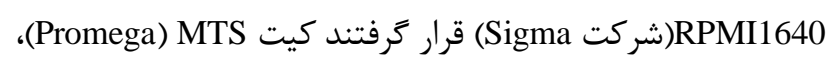
يك آزمون كمى و رنتىى است. احياء MTS، بلوسيله آنزيم

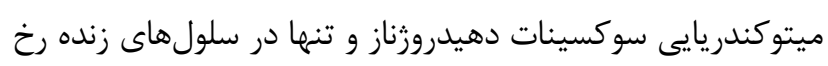

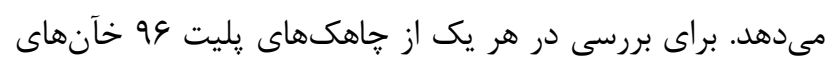

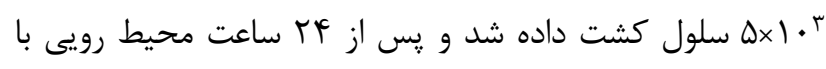

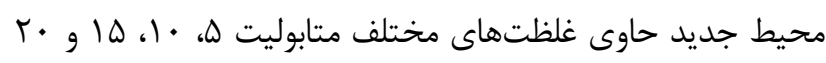
ميلى

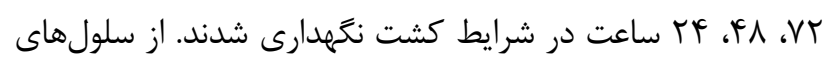

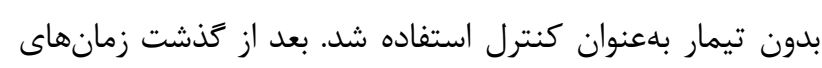

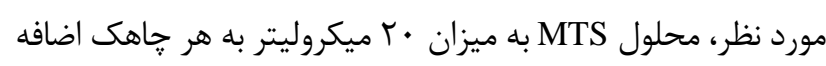

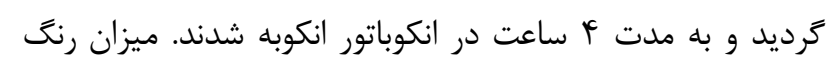

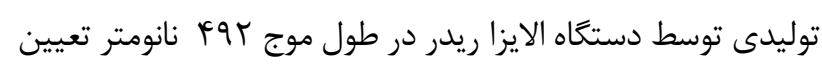

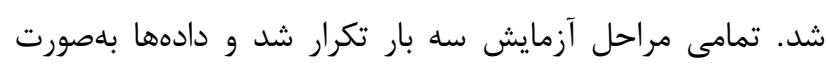

$$
\text { ميانگين SD }
$$

القاى آيويتوزيس در رده سلولى PC-3، از طريق تست

FITC Annexin V Annexin V-FITC/PI محصو

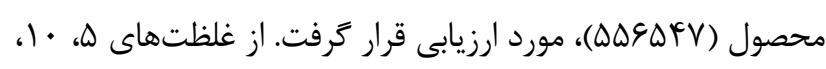

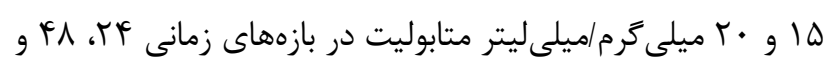

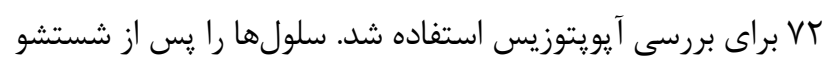

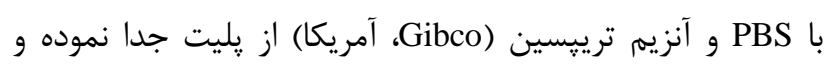

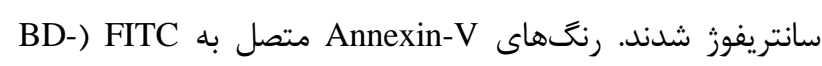
(PI Propidium iodide; BD Pharmingen) و (BD Pharmingen به ميزان ه ميكروليتر به مدت لها دقيقه در دماى اتاق و محيط

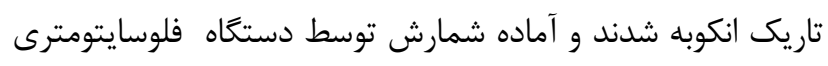

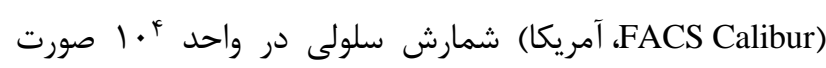

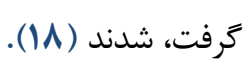

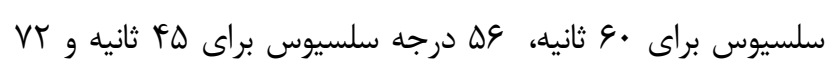

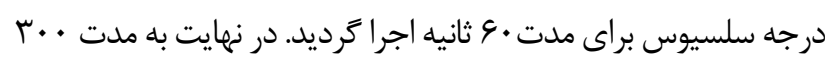
ثانيه نيز عمل طويلسازى نهايى در VT در جه سلسيوس انجام شد (IV ) (IV). سيس براى اطمينان از تكثير زن 16S rRNA، محصول PCR

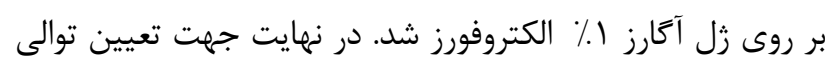

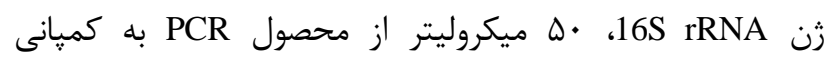

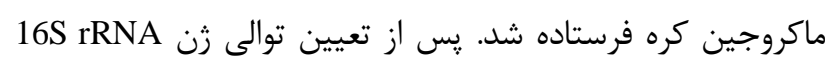
جداشده، توالى زنى بهدست فرآمده با استفاده از نرمافزار موجود در سايت NCBI ارزيابى شد (IV).

\section{كشت Bacillus licheniformis}

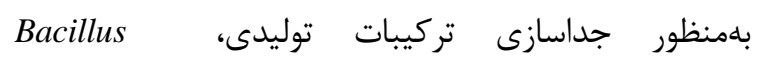
licheniformis

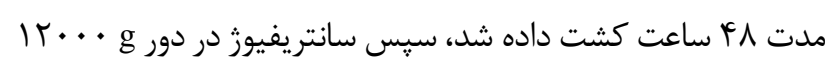

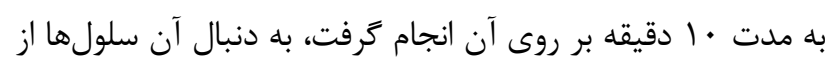

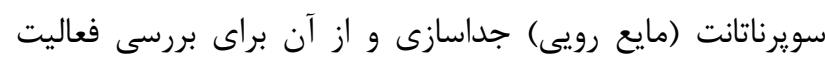

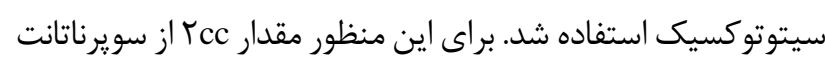

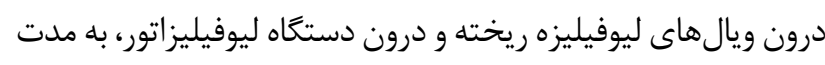

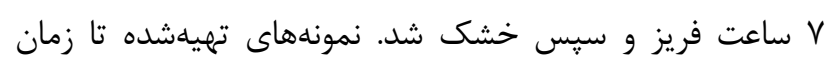

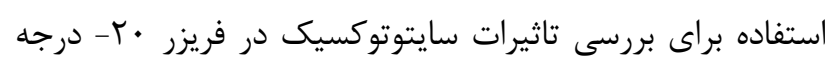
سلسيوس نتخهدارى شد (If) - (If).

\section{Bacillus بر برسى تاثيرات سيتوتوكسيك سويرناتانت} PC-3 بر روى رده سلولى سرطانى licheniformis

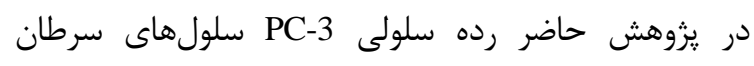

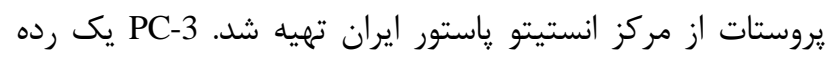

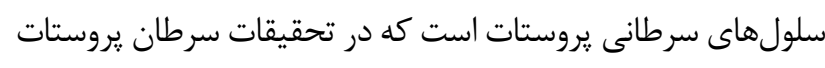

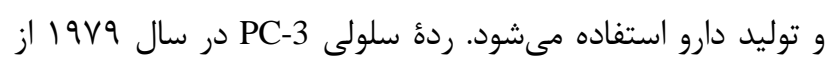

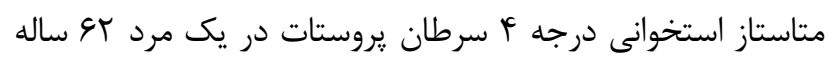

$$
\text { قفقازى كرفته شده است. }
$$

يس از انتقال فلاسك T-25 از مركز انستيتو ياستور ايران،

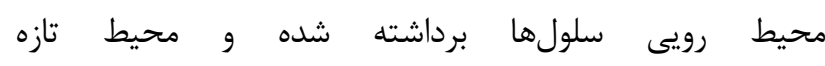
(RPMI+FBS10\%+Pen/Strep1\%)

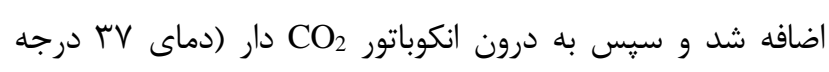
سلسيوس،

Sروهاى آزمايشى: براى بررسى تاثير سويرناتانت Bacillus licheniformis (PC-3)، سلول ها در معرض غلظتهاى مختلف قرار كرفتند. 
ميكروبى شناسايى شد. بهترين جدايه از لحاظ توليد تركيبات ضد

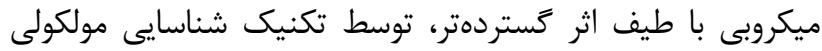

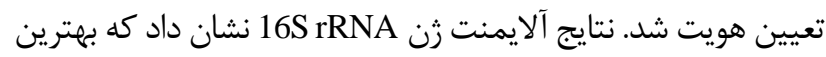
سويه از لحاظ توليد تركيبات ضد ميكروبى Bacillus licheniformis

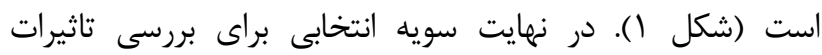
سيتوتوكسيك استفاده خرديد.

Bacillus بررسى تاثيرات سيتوتوكسيك سويرناتانت PC-3 روى رده سلولى سرطانى licheniformis مشاهدات ميكروسكويى نشاندهندة تغييرات مورفولوزى و و

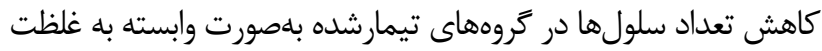

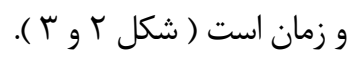

Sequence ID: $\underline{\mathrm{dbj}}|\mathrm{AB} 275356.1|$ Length: 1501

$\begin{array}{ccccc}\text { Score } & \text { Expect } & \text { Identities } & \text { Gaps } & \text { Strand } \\ 55 \text { bits(300) } & 2 \mathrm{e}-154 & 348 / 371(94 \%) & 4 / 371(1 \%) & \text { Plus/Plus }\end{array}$

Query 16 TTGCGGC-CTCTAAGGTGACTGCCGGTGA-TAACCGGAGGAAgggggggATGACGTCAAA 73 ||| ||| ||||||||||||||||||||| ||||||||||||| |||||||||||||||

Sbjct 1126 TTG-GGCACTCTAAGGTGACTGCCGGTGACAAACCGGAGGAAGGTGGGGATGACGTCAAA 1184

Query 74 TCATCCTGCCCCTTATGACCTGGGCTACCCACGTGCTACAATGGGCATAACAAAGGGCAA 133 ||||| |||||||||||||||||||||| |||||||||||||||||| |||||||||||

Sbjct 1185 TCATCATGCCCCTTATGACCTGGGCTACACACGTGCTACAATGGGCAGAACAAAGGGCAG 1244

Query 134 CGAACCCCCGAGGCTAAGCCAATCCCACAAATCTGTTCTCAATTCGGATCGCAATCTGCA 193 ||||| || |||||||||||||||||||||||||||||||||||||||||||| ||||||

Sbjct 1245 CGAAGCCGCGAGGCTAAGCCAATCCCACAAATCTGTTCTCAGTTCGGATCGCAGTCTGCA 1304

Query 194 ACTCCACTGCCTGAAGCTGGAATCCCTAGTAATCCCGGATCAACATGCCGCGGTGAATAC 253 |||| ||||| ||||||||||||| ||||||||| ||||||| |||||||||||||||||

Sbjct 1305 ACTCGACTGCGTGAAGCTGGAATCGCTAGTAATCGCGGATCAGCATGCCGCGGTGAATAC 1364

Query 254 CTTCCCGGGCCTTGTACACACCGCCCGTCACACCACGAGAGTTTGTAACACCCGAAGTCG 313 |||||||||||||||||||||||||||||||||||||||||||||||||||||||| $\mid$

Sbjct 1365 GTTCCCGGGCCTTGTACACACCGCCCGTCACACCACGAGAGTTTGTAACACCCGAAGTCG 1424

Query 314 GTGAGGTAACCTTTTGGAACCAGCCGCCCAAGGTGGGACAGATGATTGGGGTGAAGTCGT 373 ||||||||||||||||||||||||||||||||||||||||||||||||||||||||

Sbjct 1425 GTGAGGTAACCTTTTGGAGCCAGCCGCCGAAGGTGGGACAGATGATTGGGGTGAAGTCGT 1484

Query 374 A-CATGTAACC 383

| || ||||||

Sbjct 1485 AACAGGTAACC 1495

شكلا. آناليز آلاينمنت زن 16S rRNA سويه انتخابى 

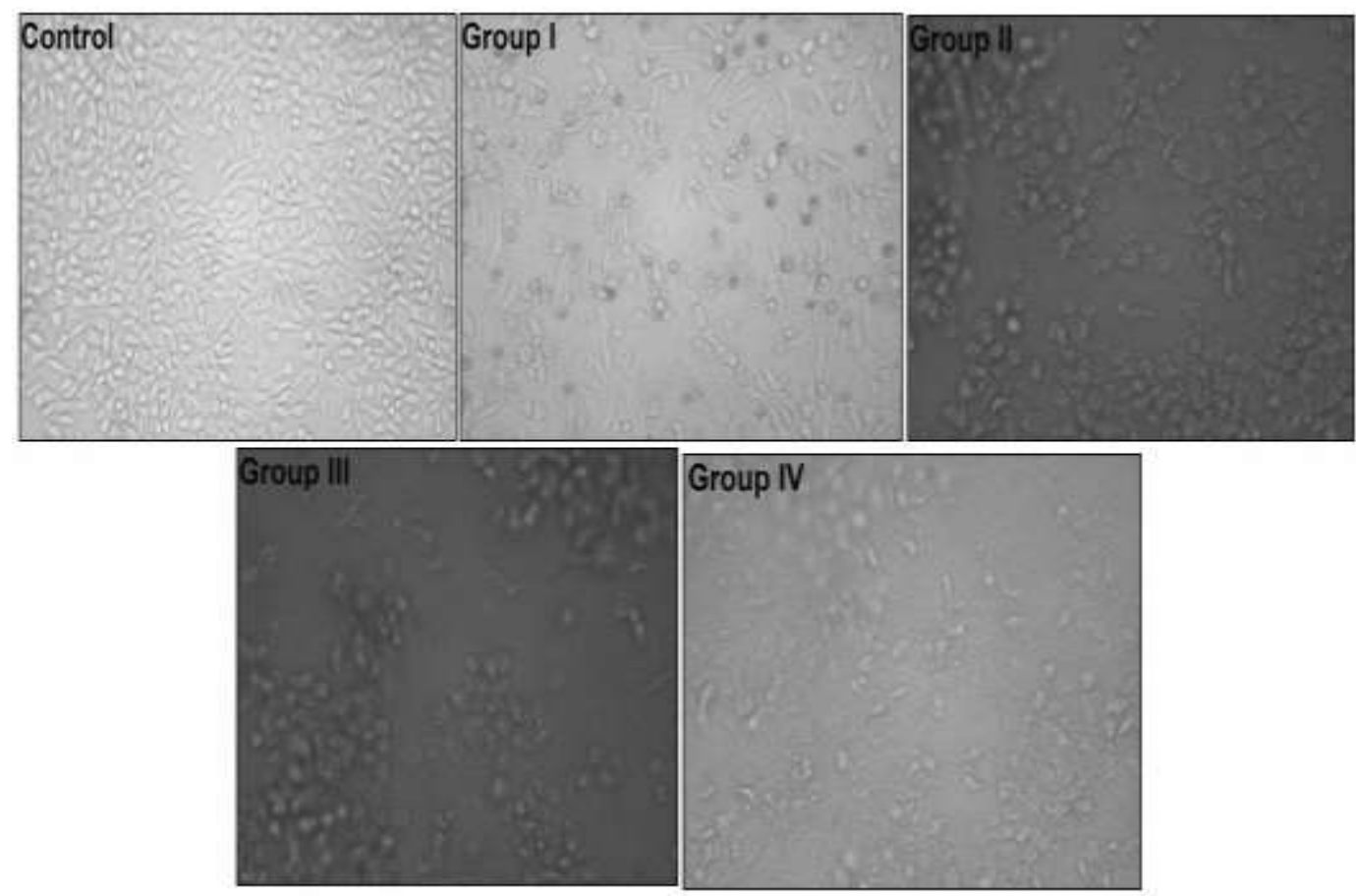

شكل r. تاثير غلظتهاى مختلف سوير ناتانت Bacillus licheniformis بر رده سلولهاى PC-3 در مدت زمان ^ץ ساعت انكوباسيون
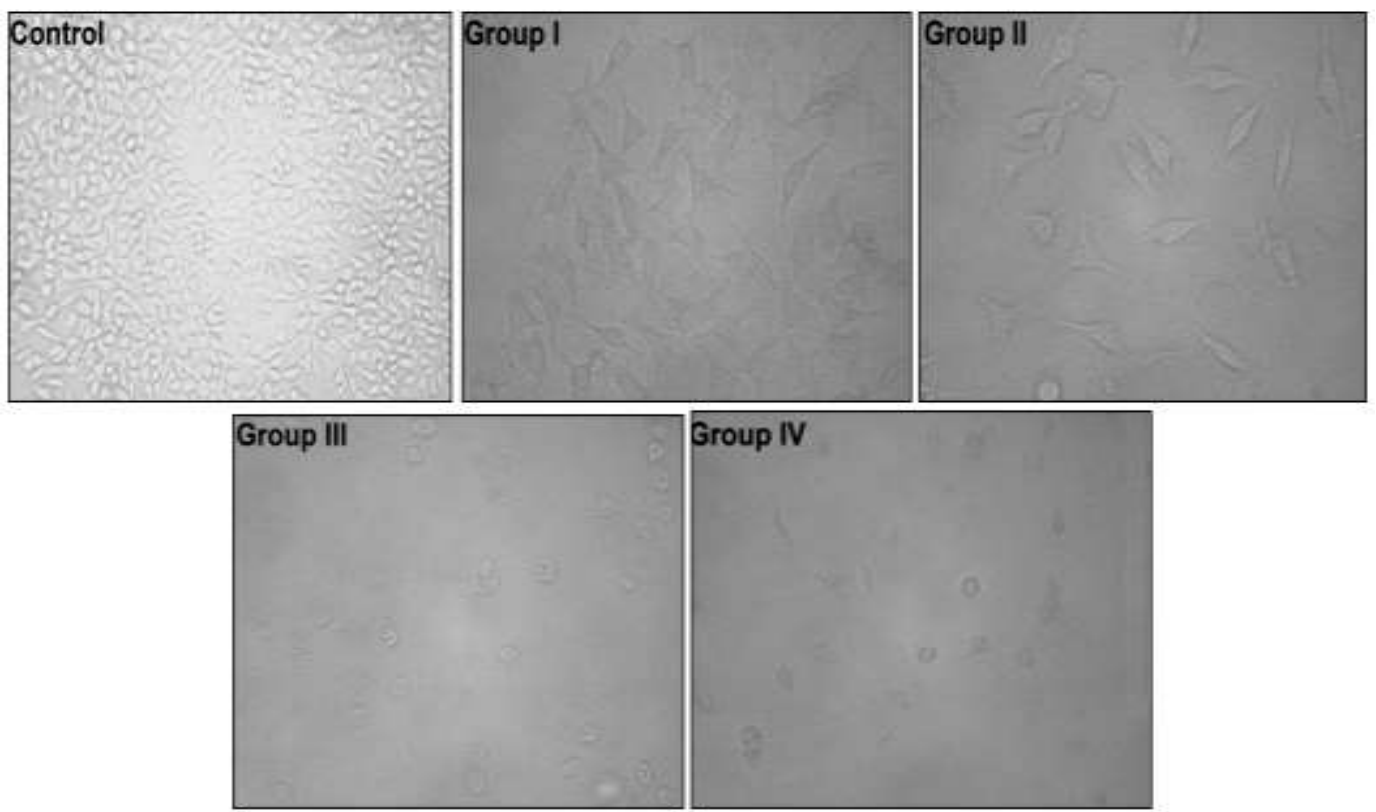

شكل Y. تاثير غلظتهاى مختلف سويرناتانت Bacillus licheniformis بر رده سلول هاى PC-3 در مدت زمان VY ساعت انكوباسيون

صورت وابسته به دوز كاهش ييدا كرد كه اين اختلاف نسبت به زروه كنترل به جز گروه I معنى Iار بود (I • (

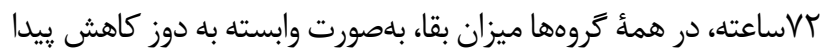

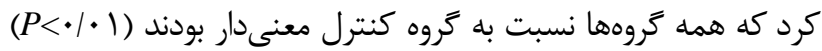

(شكل (9). (ش)
تاثير غلظتهاى مختلف سويرناتانت در رده PC-3 بر ميزان بقا،

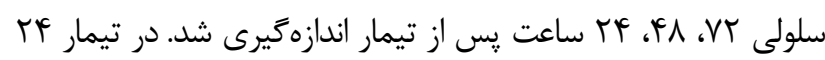

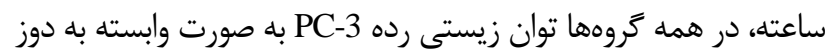

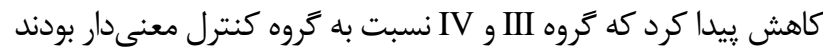

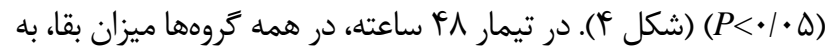




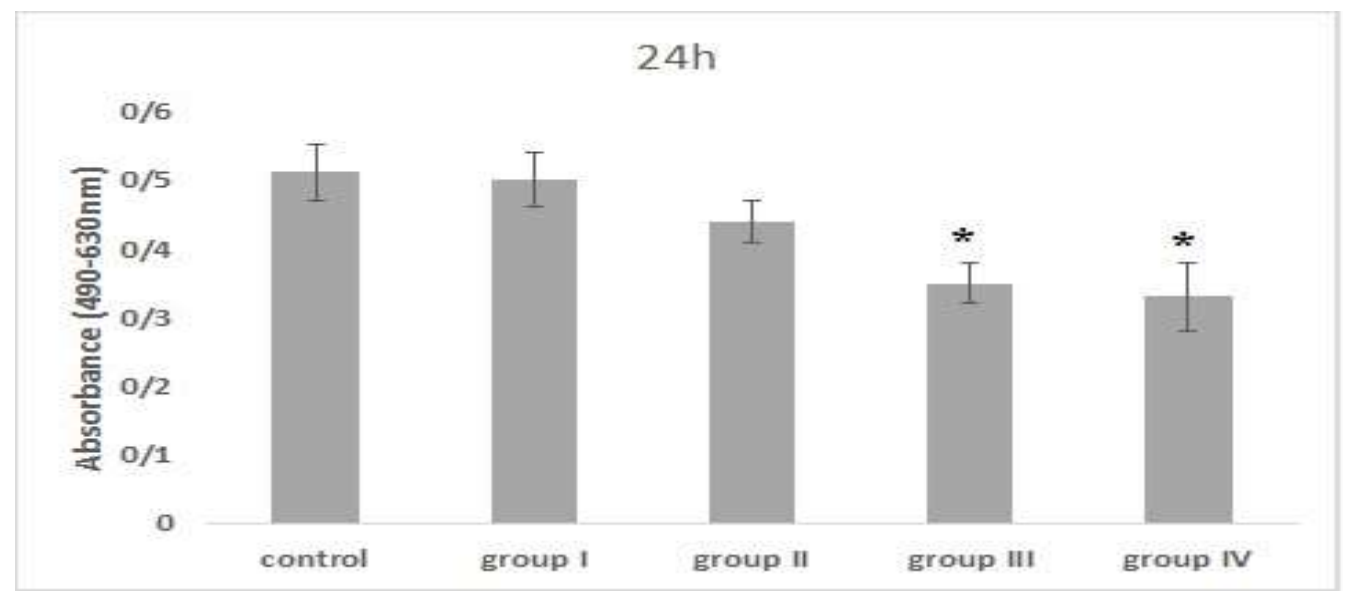

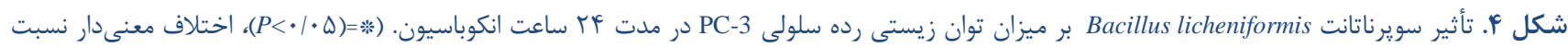

به گروه كنترل)

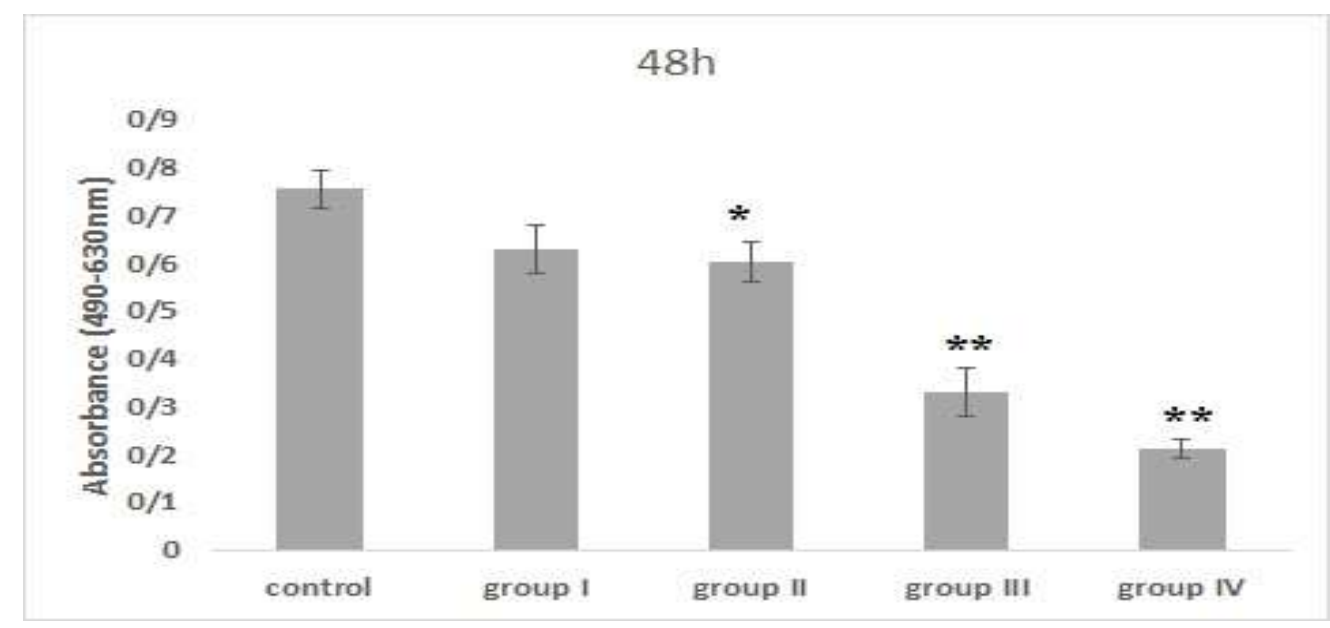

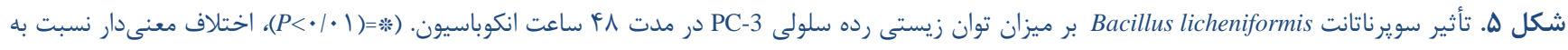

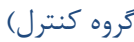

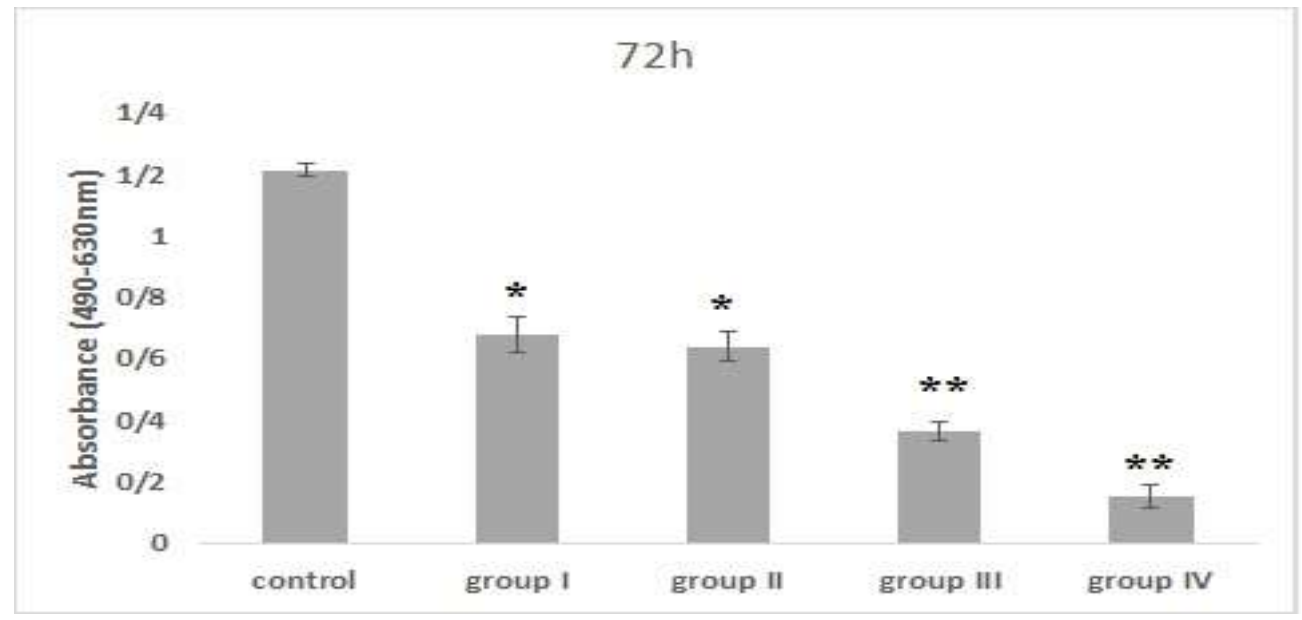

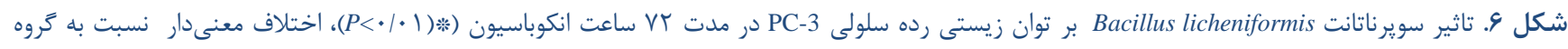
كنترل، 
همان طور كه در شكلهاى V، 9 و 11 ديده مىشود، درصد

سلولهاى زنده در ساير گروهها در هر سه زمان انكوباسيون نسبت به كروه كنترل كاهش را نشان مىدهد كه اين اختلاف از نظر

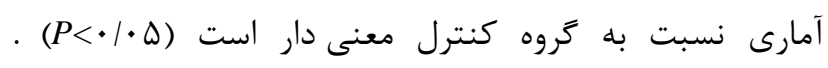
همجنين درصد سلولهايى كه در مرحله ابتدايى و انتمايى آيويتوزيس هستند با افزايش غلظت سويرناتانت و طول زئن زمان

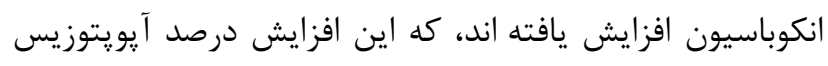

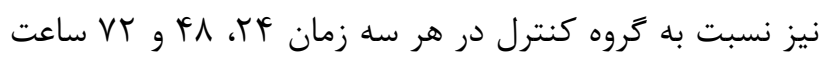

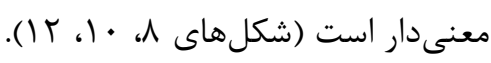

براى بررسى ميزان آيويتوزيس از تست آنكسين V-FITC

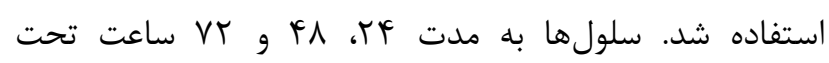
غلظتهاى مختلف سويرناتانت قرار گرفتند و تاثير غلظتهاى مختلف سويرناتانت در رده سلولى PC-3 بر ميزان آيويتوزيس

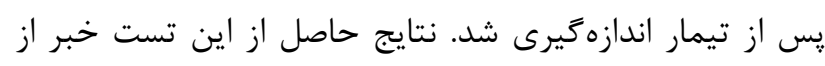
افزايش درصد مرى سلولى در گروههاى آزمايشى تحت تيمار

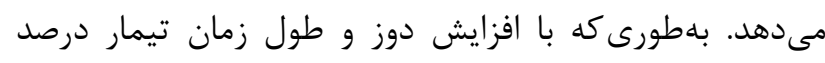
سلولهاى زنده در گروههاى تحت تيمار در مقايسه با گروه كنترل كاهش يافته است.
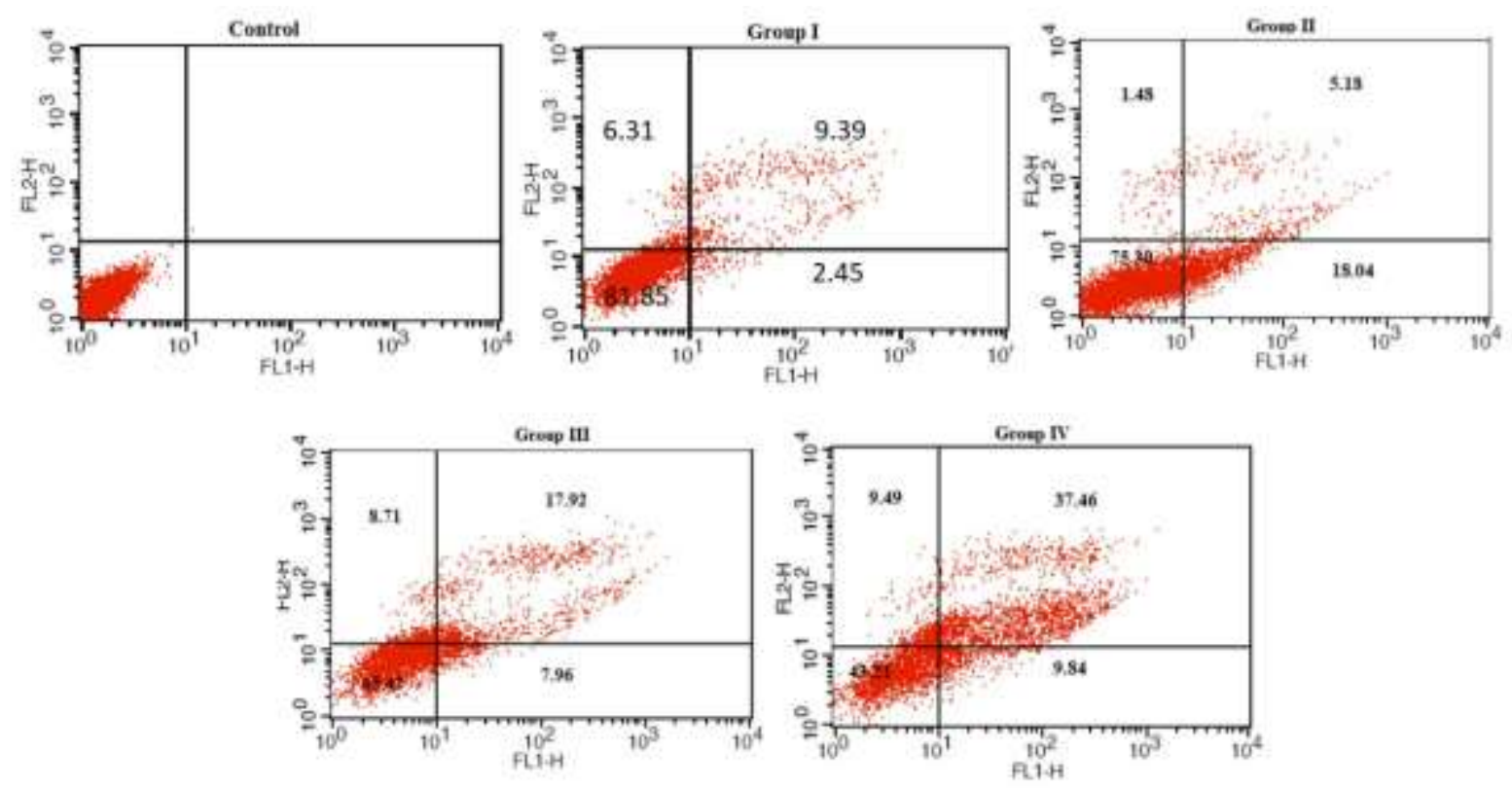

شكل V. تاثير سويرناتانت Bacillus licheniformis بر آيويتوزيس سلولهاى PC-3. سلولهاى PC-3 با • †-ه ميلى كرم/ميلىليتر از سويرناتانت به مدت F ب ساعت انكوبه شدند.

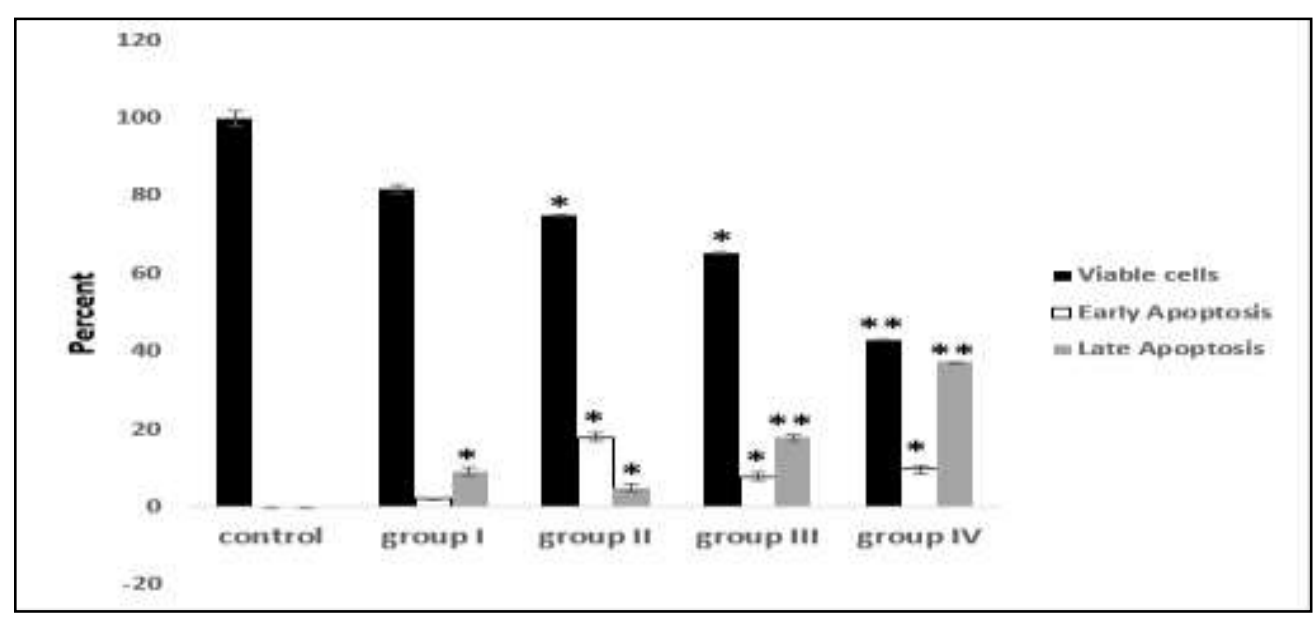

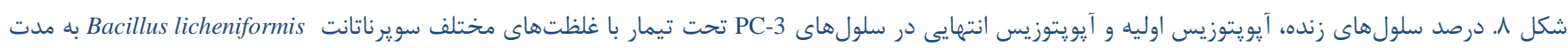
. 

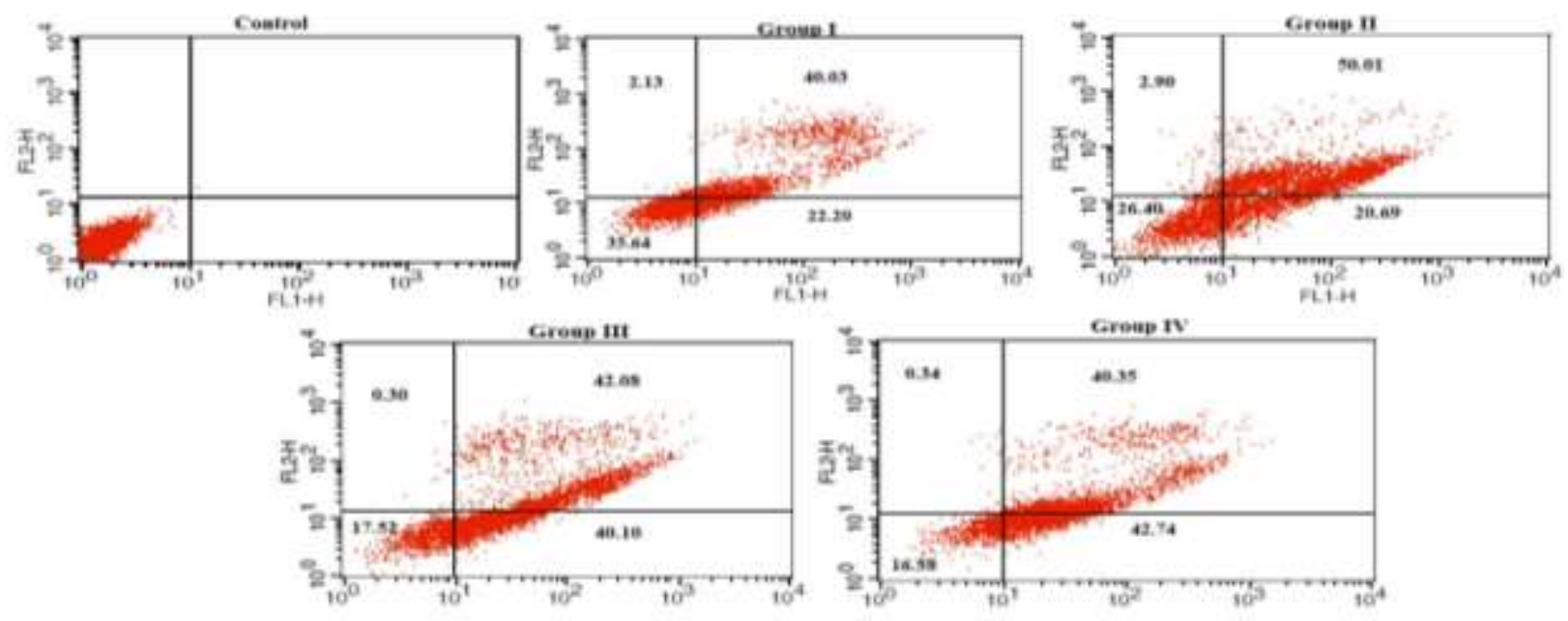

شكل 9.

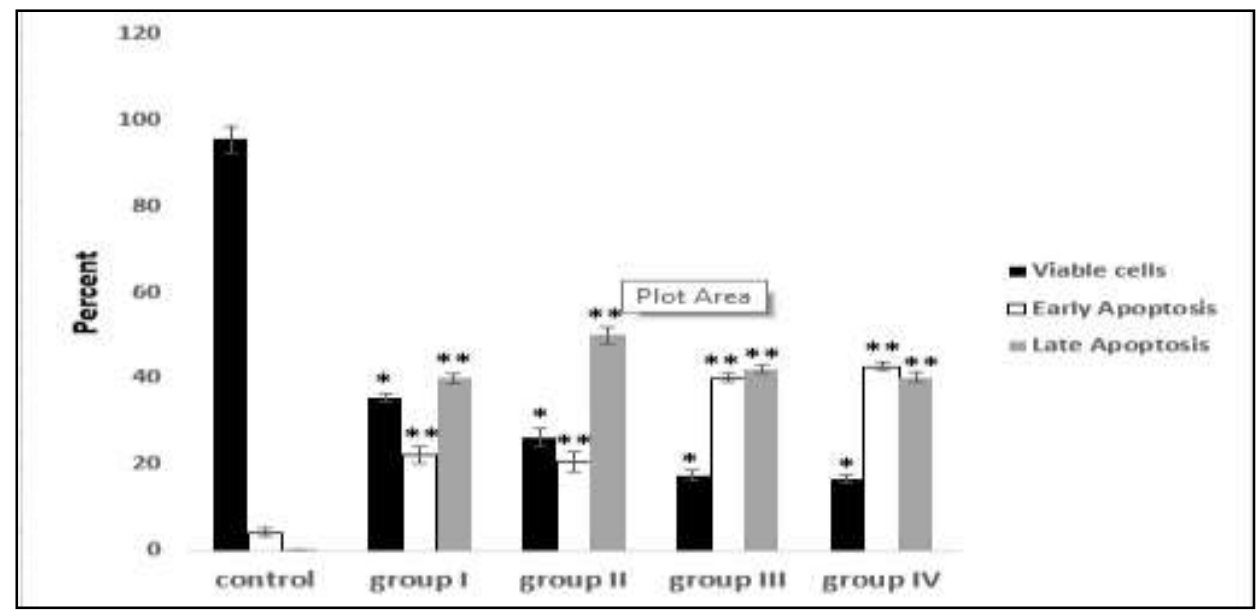

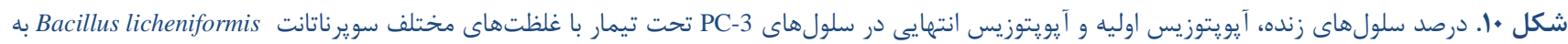

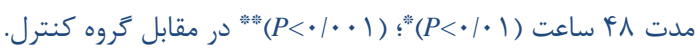
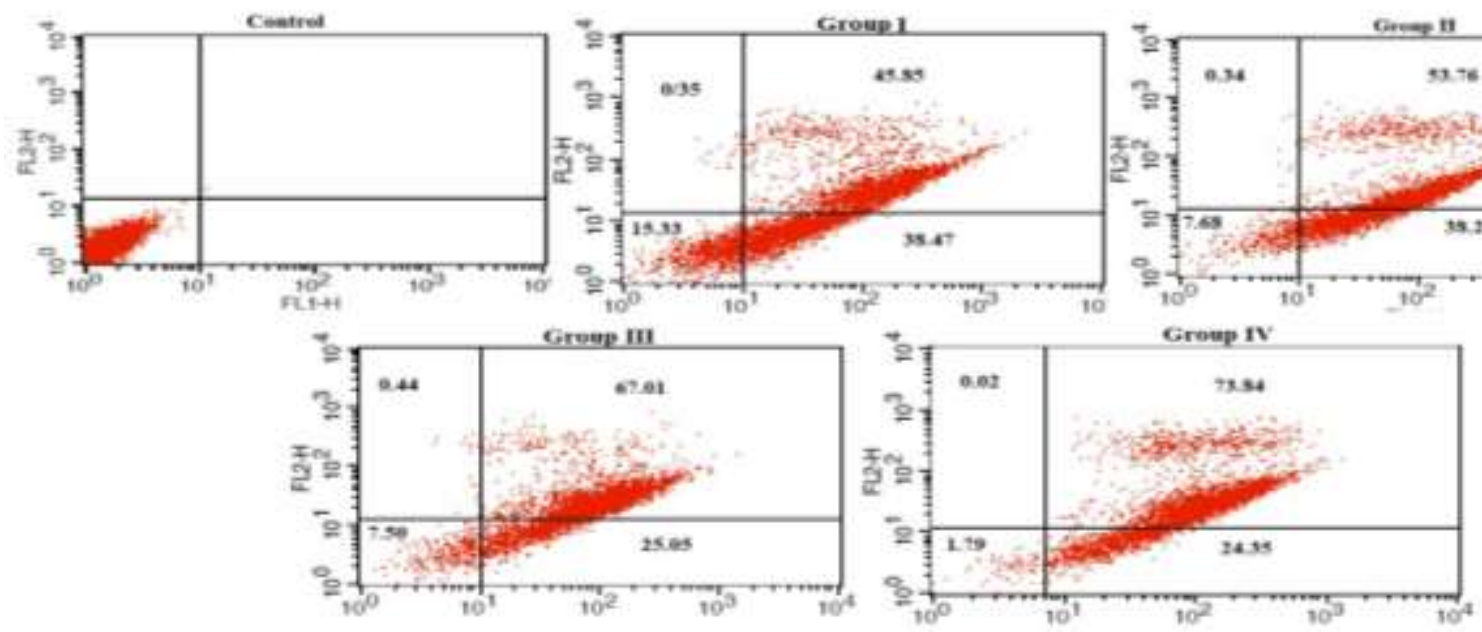

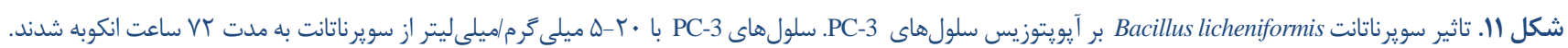




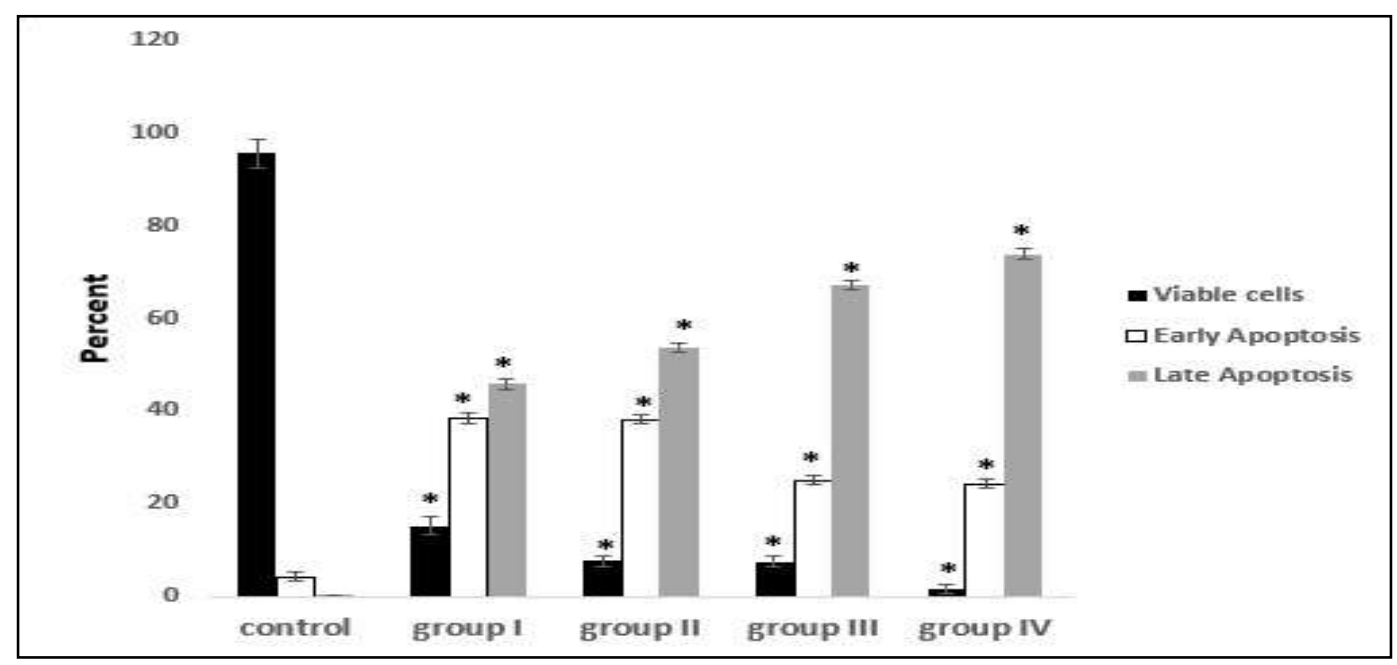

Bacillus licheniformis تحت تيمار با غلظتهاى مختلف سويرناتانت PC-3 ترا. درصد سلولهاى زنده، آيويتوزيس اوليه و آيويتوزيس انتهايى در سلولهاى

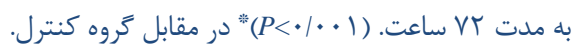

كه اين كاهش توان زيستى در خروه III و IV نسبت به كروه كنترل

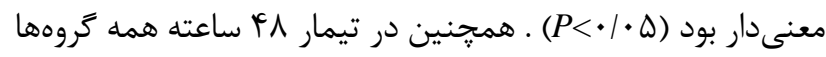

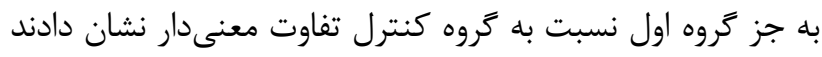

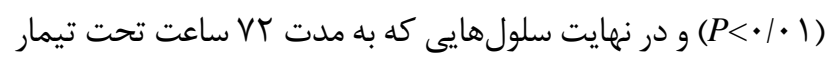
غلظتهاى مختلف سويرناتانت قرار كرفته بودند، در همه كر كروهنا

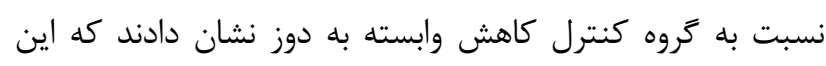

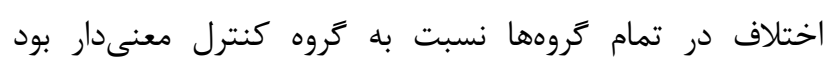
(P<•/・1)

Phonnok

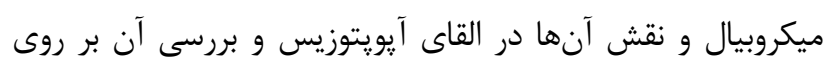

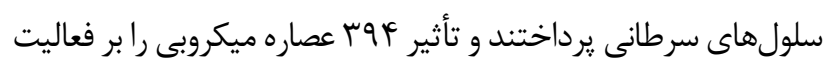

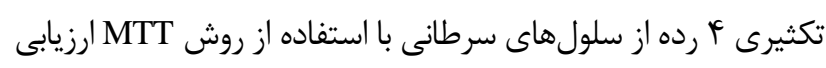

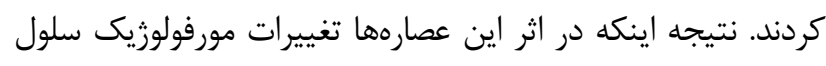

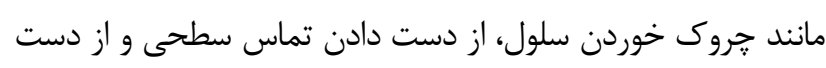

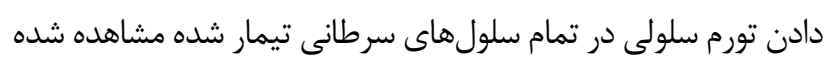

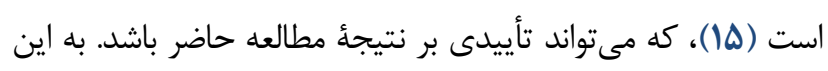

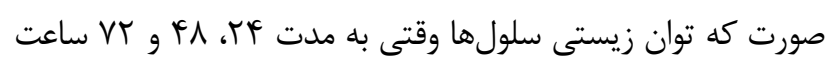

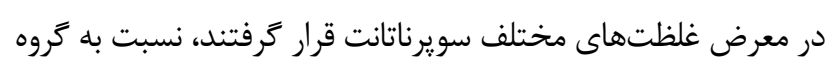
كنترل كاهش وابسته به غلظت نشان دادند.

Tuo

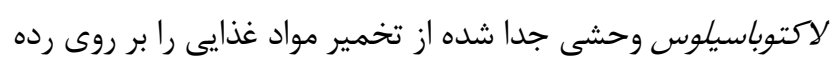

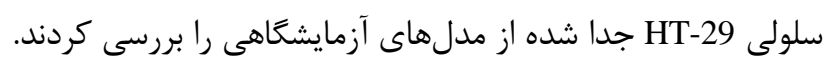

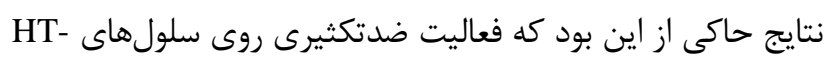

\section{بحث}

با توجه به كسترش سرطان بلعنوان يكى از مهمترين و

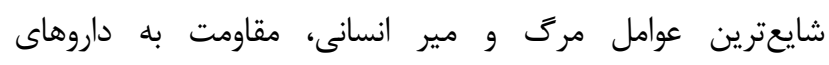
شيمىدرمانى و مضرات عديده و كاه انكوزنيك اين دسته از ازئ داروها،

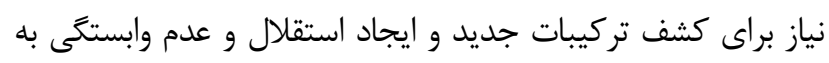

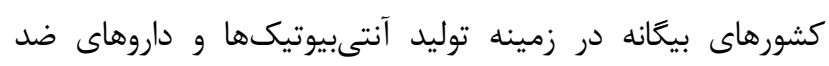
سرطانى حس مىشود. از سوى ديكر، با توجه به اينكه مطالعات نادرى دئي

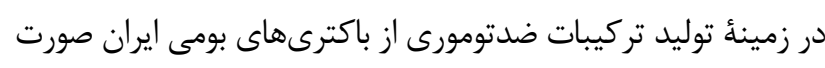

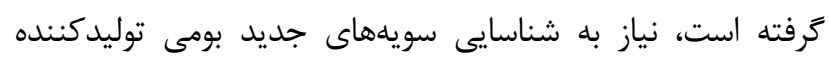

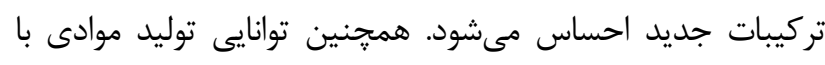

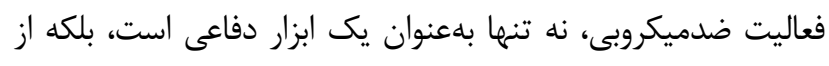

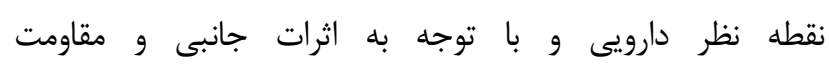

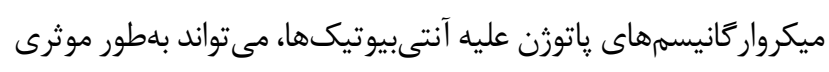

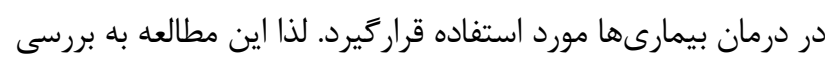

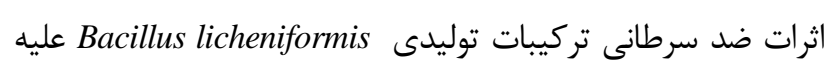

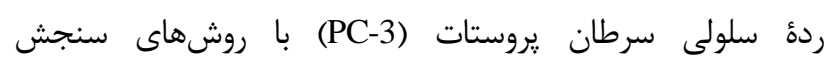

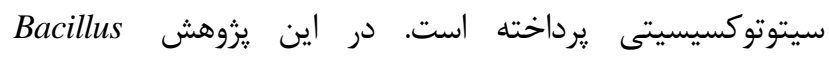

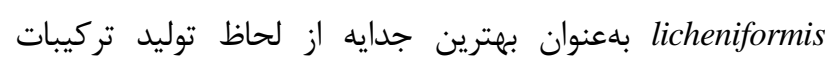

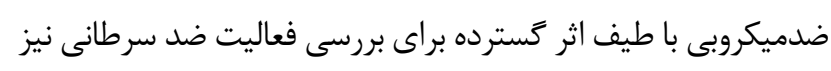

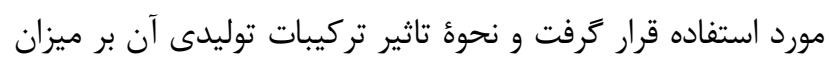

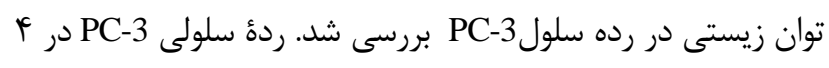

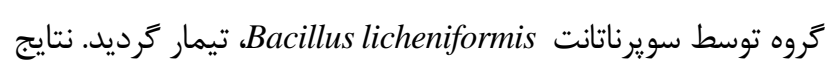

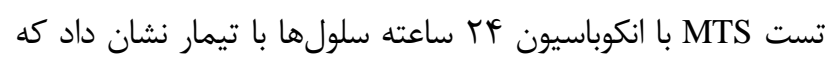

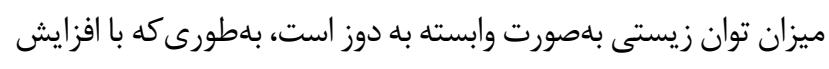

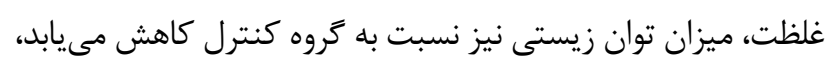


براى بررسى خواص ضدسرطانى و سلول كشى از اجزاى مختلف إندي

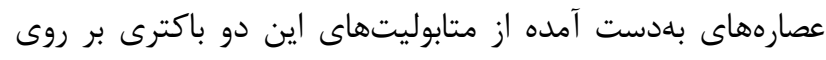

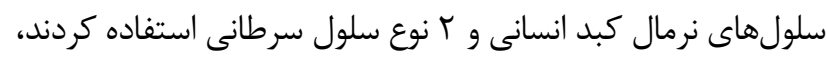

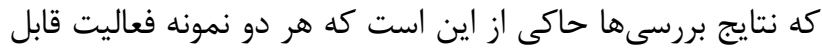

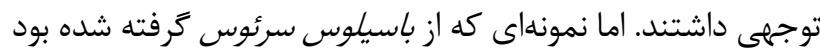

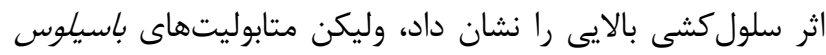

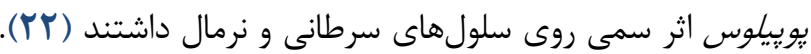

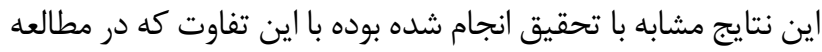
حاضر هيج اثر سمى روى سلولهاى نرمال مشاهده نكرديد. Vazquez-Rivera تأثير سميت سلولى جرخه دى ييتيدها از سودوموناس آئروزينوزا را در آيويتوزيس ردههاى سلولى سرطانى انسان مورد

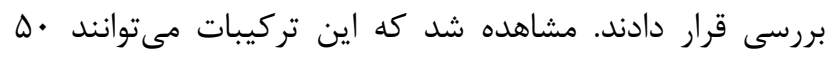
درصد اثر مهارى داشته باشند (T/Y)، كه اين نتايج تائيدى بر نتايج بلهدست آمده در مطالعه حاضر است.

Pasiar

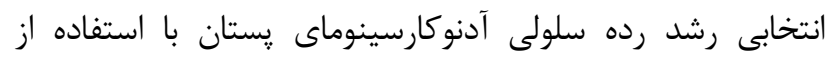

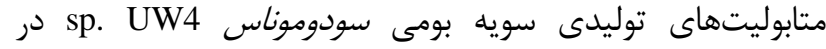

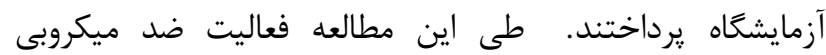

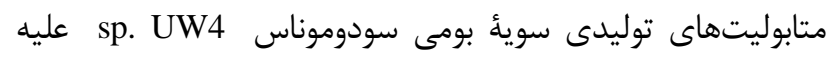
برخى از باكترىهاى بيمارىزا بررسى شد. براى بررسى فعاليت

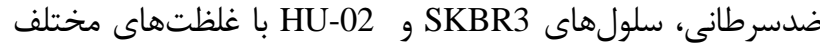

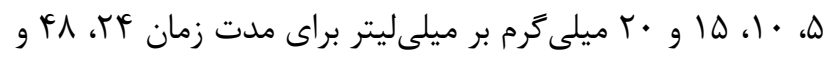

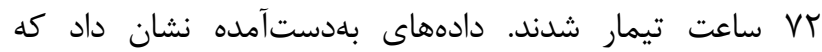
سودوموناس sp. UW4 ، قادر به توليد متابوليتهاى ضدميكروبى

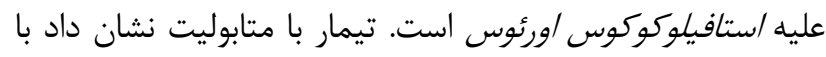
افزايش غلظت بهصورت وابسته به دوز و زمان، توان زيستى سلولها

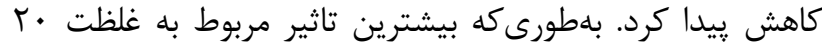

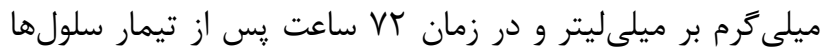

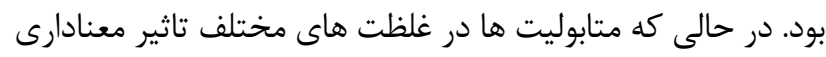
بر سلول هاى فيبروبلاست نرمال نداشت (1) كه اين نتايج تائيدى

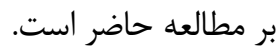

Zhang و همكاران در سال Vا I Y به بررسى خاصيت ضد

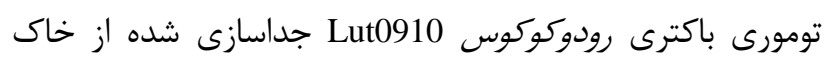
آلوده يرداختند. اثرات آن متابوليتها روى دود دو رده سلول سرطانى كبدى (HepG2) و سرطان رحم (Hela) مورد بررسى قرار ترفت. تيمار سلولهاى سرطانى مورد مطالعه با عصاره استخراجشده از مراز
29 را فقط سويه لاكتوباسيلوس كورينه فرميس داشت و توانست رشد سلولهاى HT-29 را مهار كند (19). كه در مطالعه حاضر نيز غلظتهاى مختلف سويرناتانت Bacillus licheniformis، توانست رشد رده سلولى PC-3 را مهار كند. Moosavi

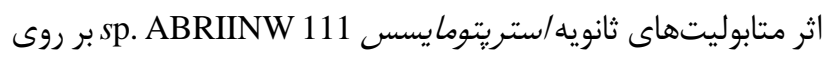

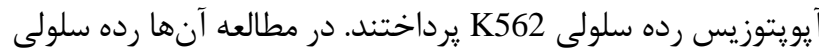

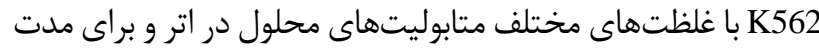

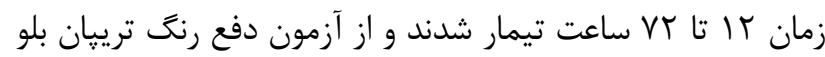
و آزمون قطعه قطعه شدن DNA به ترتيب براى بررسى مهار رشد آندان و وقوع آيو يتوزيس استفاده شد. دادهها نشان داد كه متابوليتهاى

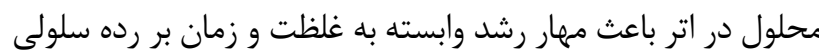

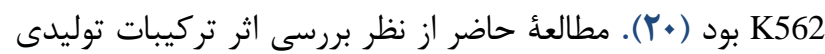

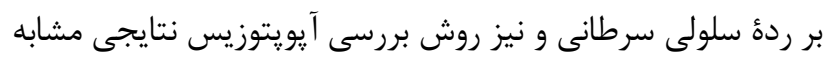

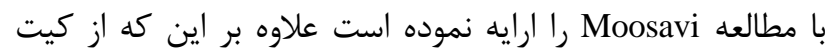
آنكسين و روش فلوسايتومترى در مطالعه حاضر استفاده شده است. Parsaseresht بررسى تاثير متابوليتهاى ثانويه لاكتوباسيلوس رامنوسوس

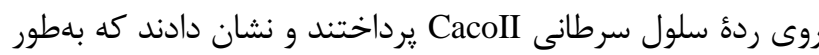
ميانگَين متابوليتهاى لاكتوباسيلوس رامنسوس

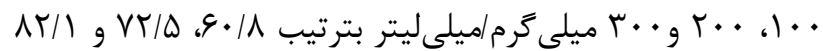
درصد رشد سلولهاى سرطانى CacoII را مهار كردند (ع). اين

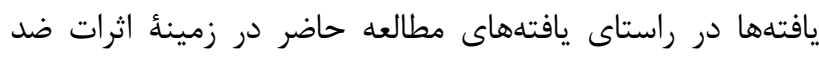
سرطانى تركيبات توليدى ميكروبى بوده است.

Mahmoudi Aslzadeh

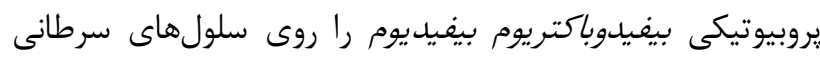

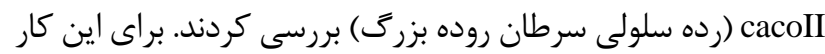

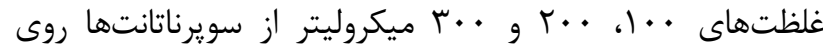

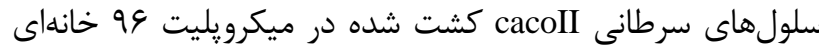

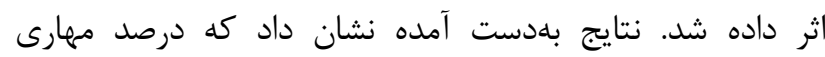

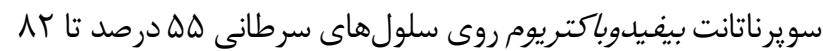

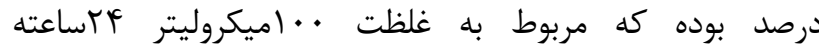

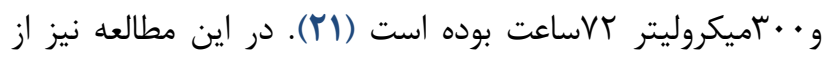
سويرناتانت باكترى انتخابى استفاده و نتايج مشابهى كرفته شد. Vijaya Kumar باكترىهاى باسيلوس سرئوس و باسيلوس يوييلوس را كه از

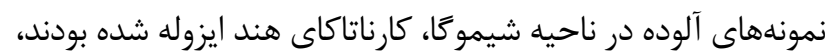




$$
\text { نتيجه تيرى }
$$

نتايج بهدستآمده از بررسى تست MTS و آنكسين نشان داد كه ميزان آيويتوزيس در رده سلولى PC-3 با افزايش غلظت سويرناتانت Bacillus licheniformis به ميزان قابل توجهى افزايش مىيابد. لذا با توجه به اينكه تكثير سلولى و آيويتوزيس نامنظم يكى از مشخصههاى سرطان است بنابراين مىتوان از سويرناتانت Bacillus licheniformis آيويتوزيس در ييش گيرى و درمان سرطان يروستات استفاده كرد.

$$
\text { سياسگز ارى }
$$

بدين وسيله مراتب قدردانى و تشكر خود را از تمام كسانى كه در طول انجام اين يزوهش همكارى كردند، اعلام مى نماييم. شايان

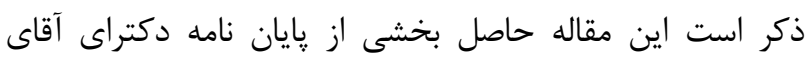

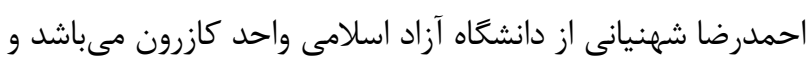
هزينه هاى مالى اين تحقيق به عهده محققين بوده است.

$$
\text { تعارض در منافع }
$$

در انجام مطالعهُ حاضر، نويسندگًان هيجزَّنه تضاد منافعى نداشتهاند.

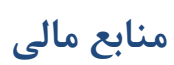

اين مقاله يزوهشى مستقل است كه بدون حمايت مالى

$$
\text { سازمانى انجام شده است. }
$$

\section{Referance}

1. Zhang XG, Liu ZY, Liu JW, Zeng YL, Guo GJ, Sun QY. Antitumor activity of a Rhodococcus sp. Lut0910 isolated from polluted soil. Tumor Biol. 2017; 39 (6): 1-9. [DOI:10.1177/1010428317711661] [PMID]

2. Baserisalehi M, Bahador N. Evaluation of soil origin Pseudomonas sp. for production of bioactive compounds.J Biol Sci. 2013; 13 (3): 152-7. [DOI:10.4414/pcd.2013.00352]

3. Cleveland J, Montville TJ, Nes IF, Chikindas ML. Bacteriocins: safe, natural antimicrobials for food preservation. Int J Food Microbiol. 2001; 71 (1): 1-20. [DOI:10.1016/S0168-1605(01)00560-8]

4. Deutsch E, Maggiorella L, Eschwege P, Bourhis J, Soria JC, Abdulkarim B. Environmental, genetic, and molecular features of prostate cancer. Lancet Oncol. 2004; 5 (5): 303-3. [DOI:10.1016/S1470-2045(04)01468-8]
باكترى رودوكوكوس Lut0910 موجب تاخير در تكثير سلولى در يك الكوى وابسته به دوز گرديد. همجنين تجويز خوراكى عصاره باكترى ذكر شده به موشهاى داراى تومورهاى مشخص منجر به به دوريه مهار رشد تومور در مقايسه با گروه كنترل گرديد (1). دادههاى اين مطالعه در زمينه اثرات سيتوتوكسيك تركيبات توليدى ميكروبى در راستاى دادههاى مطالعه حاضر بوده است. و همكاران در سال IV Dehnad

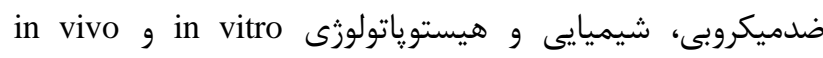
متابوليتتهاى ثانويه باكترى /ستريتومايسس لويس جديس فاسازى شده

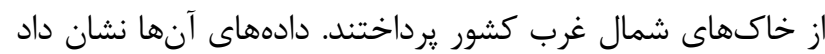
كه تنها متابوليت اترى روى تمام سوشهاى ميكروبى گرممثبت و منفى اثر داشت. نتايج حاصل از بررسى هيستوياتولوزيكى نشان داد

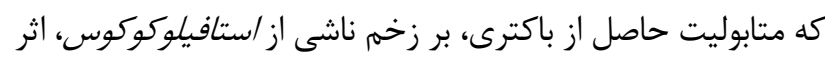
ترميمى قابل توجهى دارد. اثرات ضد ميكروبى و ضد تومورى مى تواند

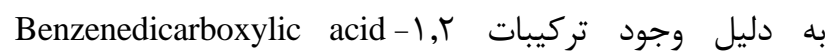
بis(2-ethylhexyl) phthalate gisooctyl ester باشد (YF)، كه اين نتايج در راستاى يافتههاى مطالعه حاضر در زمينه اثرات ضدسرطانى تركيبات توليدى ميكروبى است.

5. Muehlenbein MP, Bribiescas RG. Testosterone mediated immune functions and male life histories. Am J Hum Biol. 2005; 17: 527-58. [DOI:10.1002/ajhb.20419] [PMID]

6. Wein A, Kavoussi L, Partin A, Craig P. Campbell-walsh Urology. 11th ed. Elsevier; 2015.

7. Wilkinson AN, Brundage MD, Siemens R. Approach to primary care follow-up of patients with prostate cancer. Can Fam Physician. 2008; 54 (2): 204-10.

8. Jewett MA, Fleshner N, Klotz LH, Nam RK, Trachtenberg J. Radical prostatectomy as treatment for prostate cancer. CMAJ. 2003; 168 (1): 44-5.

9. Fleshne N, Al Azab R. Prostate cancer: chemoprevention update 2005. Can J Urol. 2005; 12 (2): 2-4.

10. Pollack A, Zagars GK, Smith LG, Lee JJ, Von Eschenbach AC, Antolak JA, et al. Preliminary results of a randomized radiotherapy dose-escalation study comparing 70 Gy with 78 Gy for prostate cancer. J Clin 
$\begin{array}{lllll}\text { Oncol. } & 2000 ; & 18 & \text { (23): } & 3904-11 .\end{array}$ [DOI:10.1200/JCO.2000.18.23.3904] [PMID]

11. Bamzadeh Z, Baserisalehi M, Bahador N, Hejazi H. Screening of soil Streptomyces and characterization of their bioactive compounds. J Health Med. 2013; 7 (8): 2293-00.

12. Demain AL, Sanchez S. Microbial drug discovery: 80 years of progress. J Antibiot. 2009; 62 (1): 5-16. [DOI:10.1038/ja.2008.16] [PMID] [PMCID]

13. Ibarguren C, Audisio MC, Torres EM, Apella MC. Silicates characterization as potential bacteriocin-carriers. Innov Food Sci Emerg. 2010; 11 (1): 197-02. [DOI:10.1016/j.ifset.2009.10.002]

14. Pourhavashemi S, Bamzadeh Z, Rouhi L, Zia-Jahromi N. Survey the effect of produced metabolites by native Pseudomonas sp. UW4 on p53 gene expression in SKBR-3 breast cancer cell line. J Shahid Sadoughi Uni Med Sci. 2018; 26 (5): 399-09.

15. Phonnok S, Tanechpongtamb WU, Wangsatayanon BT. Anticancer and apoptosis-inducing activities of microbial metabolites. J Biotechnol. 2010; 13 (5): 1-12. [DOI:10.2225/vol13-issue5-fulltext-7]

16. Parsaseresht L, Fazeli M, Samadi N, Jamalifar H, EIDI A, Mahmudiaslzadeh $\mathrm{H}$. Effect of metabolites produced by Lactobacillus Rhamnosus GG (probiotic bacteria) on the growth of human colon cancer cell line CacoII. Iran J Biol. 2013; 25 (4): 484-92.

17. Bamzadeh Z, Baserisalehi M, Bahador N, Hejazi H. Isolation and identification of antimicrobial producing Actinomycetes from Shiraz soil farms. J Microbial. 2012; 4 (16): 7-19.

18. Pasiar M, Rouhi L, Bamzadeh Z, Hejazi H. In vitro selective growth inhibition of breast adenocarcinoma cell lines by Pseudomonas sp. UW4 metabolites. TUMJ. 2016; 74 (9): 614-20.

19. Tuo YF, Zhang LW, Yi HX, Zhang YC, Zhang WQ, Han $\mathrm{X}$, et al. Short communication: Antiproliferative effect of wild Lactobacillus strains isolated from fermented foods on HT-29 cells. J Dairy Sci. 2010; 93: 2362-6. [DOI:10.3168/jds.2010-3069] [PMID]

20. Moosavi MA, Ghanbarvand F, Dehnad AR. Growth inhibition and induction of apoptosis by ether soluble metabolites of Streptomyces sp. ABRIINW 111 in Human Myeloid Leukemia K562 cell line. Cell Tissue Res. 2011; 2(3): 225-34.

21. Mahmoudi Aslzadeh H, Fazeli M, Eaidi A, Samadi N, Jamalifar H, Parsaseresht L. Study of probiotic effect of Bifidobacterium bifidum on CacoII cancer cell line. Iran J Biol. 2013; 26(3): 378-85.

22. Vijaya Kumar ML, Thippeswamy B, Vasanth Raj P. Cytotoxicity and anticancer studies of Bacillus cereus and Bacillus pumilus metabolites targeting human cancer cells. Appl Biochem Microbial. 2014; 50: 619-23. [DOI:10.1134/S0003683814060088]

23. Vazquez-Rivera D, Gonzalez O, Guzmán-Rodriguez J, Diaz-Perez AL, Ochoa-Zarzosa A, Lopez-Bucio J, et al. Cytotoxicity of cyclodipeptides from Pseudomonas aeruginosa PAO1 leads to apoptosis in human cancer cell lines. Biomed Res Int. 2015; 2015: 1-9. [DOI:10.1155/2015/197608] [PMID] [PMCID]

24. Dehnad AR, Abushov R, Hamedi J, Nahaei MR, Mobaiyen H, Zendehdel A. Study of active secondary metabolites of Streptomyces levis isolated from north west soils of Iran and their in vitro and in vivo antibacterial effects. Med J Tabriz Univ Med Sci Health Serv. 2017; 39(3): 39-46. 